\title{
Micropollutant Degradation Mechanism
}

\author{
Brigita Tepuš¹, Irena Petrinić ${ }^{2}$ and Marjana Simonič ${ }^{2}$ \\ ${ }^{1}$ Municipal Enterprise Ptuj, ${ }^{2}$ University of Maribor, \\ Faculty of Chemisty and Chemical Engineering \\ Slovenia
}

\section{Introduction}

The organic pollution is a major concern during the treatment of drinking-water as organic micro-pollutants might show disruptive and toxic properties. Organic micro-pollutants are found in surface and groundwaters at different concentrations, mostly between 0,1 and 100 $\mu \mathrm{g} / \mathrm{L}$ (Panno\&Kelly, 2004).

Pesticides are known contaminants of concern. $363 \mathrm{kt}$ of pesticides were used between 1980 and 1990 in the USA. From among triazine pesticides, atrazine and its metabolites, deethylatrazine and deisopropylatrazine, can still be found in drinking-water supplies throughout the EU, due to their usage as maize and sugar beet pesticide. They are slowly biodegradable microbiologically (Reid et al, 2003). They have to be removed from drinkingwater sources because they are classified as possible human carcinogens (Legube et al, 2004). Atrazine, with the chemical name 2-chloro-4-(ethylamino)-6-(isopropylamino)-striazine $\left(\mathrm{C}_{8} \mathrm{H}_{14} \mathrm{ClN}_{5}, M_{\mathrm{CIET}}=215,7 \mathrm{~g} / \mathrm{mol}\right)$ is soluble in water at $30 \mathrm{mg} / \mathrm{L}$ and half live in soil for atrazine is 15-100 days (Ralebitso et al, 2002). Atrazine is classified as a class C carcinogen. Chromosom damage to chinese hamster egg cells were observed if they were exposed to $0,005-0,080 \mu \mathrm{mol} / \mathrm{L}$ of atrazine, within two days. Two well-known atrazine metabolites, deethylatrazine and deisopropylatrazine, were found to be potentially carcinogenic, therefore the admissible levels for each pesticide individually in water are set at $0,1 \mathrm{ug} / \mathrm{L}$, and the sum should not exceed $0,5 \mu \mathrm{g} / \mathrm{L}$ in EU (Thurman et. al, 1994). US EPA (US Environmental Protection Agency) set the total admissible levels for atrazine, deethylatrazine and deisopropylatrazine in groundwater at $3 \mu \mathrm{g} / \mathrm{L}$ (Richards et al, 1995). A study by US EPA in 2003 showed that triazines - atrazine, simazine and propazine - as well as metabolites - deethylatrazine and deisopropylatrazine in deethyl- deisopropylatrazine have the same mechanism concerning endocrine disruptions. Anumnerated compounds act the same way on human bodies, therefore, US EPA introduced the sum of all chloro-s-triazines. Atrazine removal from drinking water sources is impossible using chlorination, aeration, filtration or coagulation. Quite effective technologies include activated carbon, ozonation, membrane separatoin, and biofiltration. The most efective are RO and NF membranes (Jiang\&Adams, 2006).

During a study of atrazine degradation within concentrations ranging from 5 to $1700 \mathrm{ng} / \mathrm{L}$, the only metabolite found was deethylatrazine within a concentration range from 10-850 ng/L (Garmouna et al., 1997). 
A study of atrazine monitoring in Slovenia from 1993 to 1996 showed that atrazine concentrations were up to $7,23 \mu \mathrm{g} / \mathrm{L}$. Then they started to decrease to $0,06 \mu \mathrm{g} / \mathrm{L}$ due to the elimination of Primextra and Atrapine T in 1994 (Pintar \& Lobnik, 2001). In March, 1999 atrazine use was prohibited (Official Gazette RS, 1999).

Evidently, organic micro-pollutants represent only a minor fraction of organic pollution. The major fraction of organic pollution is attributed to natural organic matter (NOM). NOM is a heterogeneous mixture of undefined structurally complex organic compounds derived from plants, animals, microorganisms, and their waste and metabolic products. Therefore, NOM inevitably occurs in all natural water sources and, like micro-pollutants, must be removed from water sources. NOM interferes with the performances of several unit processes. NOM could be responsible for high coagulant demand, rapid clogging of filters by biofilm growth on media, rapid saturation of activated carbon beds, thereby increasing the regeneration frequency, high disinfectant demand, inhibiting the impact of disinfectants, and the rapid decay of ozone. NOM is a major membrane foulant and may inhibit the removal of organic micro-pollutants by activated carbon. NOM should be carefully considered when choosing the optimal process and design for organic removal (Haarhoff, 2010).

\section{Ozone reaction in water}

Ozone in ground and surface water reacts with dissolved organic substances (DOC) and micropollutants. Ozonation decreases the formation of disinfection by-products, such as trihalometanes (THM) and haloacetic acid (HAA). NOM influences ozone decay. Ozonation is one of the better known technologies for atrazine removal (Von Gunten, 2003). Ozone is unstable in water and its half-life ranges from a few seconds to a few hours, depending on $\mathrm{pH}, \mathrm{NOM}$, and water alkalynity. Ozone decomposition constitutes the first step of a complicated mechanism for indirect reactions, which are accelerated by initiators such as $\mathrm{OH}$-ions. The resulting radicals react instantly $\left(\mathrm{k}=108-1010 \mathrm{~L} \mathrm{~mol}^{-1} \mathrm{~s}^{-1}\right)$ and non-selectively with pollutants. The radical pathway is influenced by the type of dissolved substances in the water. This mechanism, consisting of three different steps is widely used: the initiation step - formation of superoxide anion radical $\left(\mathrm{O}_{2}^{-}\right)$, the propagation step - formation of hydroxyl radicals and re-initiation of the chain reaction, and the termination step - inhibitors (scavengers) stop the re-formation of the superoxide anion radical. The direct reaction of organic compounds with ozone is a selective process and has a slow reaction rate constant. It takes place when the radical mechanism is inhibited the oxydation of ozone with NOM is a typically second-order reaction, but with a first-order reaction with respect to ozone and to the organic compound following eqs. 1 and 2. Second- order reactions are typical for reactions of organic compounds and hydroxyl radicals following eq. 3 (Von Gunten, 2003).

$$
\begin{gathered}
\gamma_{\mathrm{NOM}}+\gamma_{\mathrm{O} 3} \rightarrow \text { products } \\
\left(-\mathrm{d} \gamma_{\mathrm{NOM}} / \mathrm{d} t\right)=k_{\mathrm{r}} \cdot \gamma_{\mathrm{NOM}} \cdot \gamma_{\mathrm{O} 3} \\
\left(-\mathrm{d} \gamma_{\mathrm{NOM}} / \mathrm{d} t\right)=k_{\mathrm{O} 3} \cdot \gamma_{\mathrm{NOM}} \cdot \gamma_{\mathrm{O} 3}+k_{\mathrm{OH}} \cdot \gamma_{\mathrm{NOM}} \cdot \gamma_{\mathrm{OH}}
\end{gathered}
$$

rNOM - NOM, mg/L

$\gamma_{\mathrm{O} 3}$ - ozone, $\mathrm{mg} / \mathrm{L}$

$\gamma_{\mathrm{OH}^{-}}-$hydroxyl radicals, $\mathrm{mg} / \mathrm{L}$

$t$ - time, $\mathrm{t}$

$k_{\mathrm{r}}-$ reaction rate constant, $\mathrm{mol} /(\mathrm{L} . \mathrm{s})$ 
$\mathrm{k}_{\mathrm{O} 3}$ - reaction rate constant for ozone, mol/(L.s)

$k_{\mathrm{OH}}-$ reaction rate constant for hydroxyl radicals, mol/(L.s)

Various reaction orders for ozone degradation from 0 to 2 have been reported (Hermannowicz, 1999). The order of reaction depends on the reaction time. Ozone reacts with organic pollutants and, as by-products, various metabolites are formed which can affect ozone decomposition. Some accelerate while others inhibit decomposition. Decomposition change can be noticed in the change of reaction order. Ozone degradation follows first reaction order in batch experiments. If the reaction time is prolonged and the concentrations of ozone are negligible in comparison with initial ozone concentractions, the reaction order changes. In reported experiment, the first-order reaction coeficients are calculated as being higher compared with batch experiments. Various data concerning first order kinetics are found in literature: $0,031-0,23 / \mathrm{min}$ for millipore water, up to $0,27-11,3$ $1 / \mathrm{min}$ for continuous systems and 0.16 to $0.361 / \mathrm{min}$ for batch systems in surface water. Batch experiments are conducted on the laboratory scale, where different conditions appear, compared with real water samples. Ozone may destroy organic components in water and, consequently, its concentration decreases.

It has been reported that concentrations of atrazine could be lowered by the formation of $\mathrm{OH}$ radicals, at $\mathrm{pH} 7.60$, because of initiation with $\mathrm{OH}^{-}$ions in water (Gottschalk, 2000).

In aqueous solutions, ozone may react with various dissolved compounds in one of two ways: either direct reaction of the molecular ozone or indirect reaction through the formation of secondary oxidants (radical species: hydroxyl radicals) during ozone decomposition in water. These different reaction pathways lead to different oxidation products, and are controlled by different types of kinetics.

\section{Indirect reactions}

Any indirect reaction of ozone with pollutants generates radicals, such as hydroxyl radicls $\left(\mathrm{OH}^{0}\right)$ which can then accelerate ozone decomposition. They react un-selective and rapidly with $k_{\mathrm{r}}=\left(10^{8}-10^{10}\right) \mathrm{L} /(\mathrm{mol} . \mathrm{s})$ (Gottschalk et al., 2000). Radical mechansms are complex and depend on various factors. Major reactions are presented in eqs. 4 to 14, based on 2 models. Mechanisms consist, basically, of 3 stages: reaction initiation, radical chain-reaction, and reaction termination.

Reaction initiation between ozone and hydroxyl ions leads to the formation of superoxide anionic radical $\mathrm{O}_{2} \cdot{ }^{-}$and hydrogen peroxide radical $\mathrm{HO}_{2}$. (see eqs. 4, 5).

$$
\begin{array}{cc}
\mathrm{O}_{3}+\mathrm{OH}^{-} \rightarrow \mathrm{O}_{2} \cdot{ }^{-}+\mathrm{HO}_{2}, & k_{\mathrm{r}}=70 \mathrm{~L} / \text { mol.s } \\
\mathrm{HO}_{2} \cdot \leftrightarrow \mathrm{O}_{2} \cdot^{-}+\mathrm{H}^{+}, & \mathrm{pK} K_{a}=4,8
\end{array}
$$

Radical chain-reaction: according to the reaction between ozone and superoxide anionic radical $\mathrm{O}_{2}{ }^{-}$ozonide anionic radical $\mathrm{O}_{3}{ }^{-}$is formed, which immediately decomposes to $\mathrm{OH}-$ radicals, following eqs. 6 to 8 .

$$
\begin{array}{cc}
\mathrm{O}_{3}+\mathrm{O}_{2}{ }^{-} \rightarrow \mathrm{O}_{3} \cdot{ }^{-}+\mathrm{H}^{+}, & k_{\mathrm{r}}=1,6.10^{9} \mathrm{~L} / \text { (mol.s) } \\
\mathrm{HO}_{3} \cdot{ }^{-} \rightarrow \mathrm{O}_{3}{ }^{-}+\mathrm{H}^{+}, & \mathrm{pK} K_{\mathrm{a}}=6,2 \\
\mathrm{HO}_{3} \cdot \rightarrow \mathrm{OH} \cdot+\mathrm{O}_{2}, & k_{\mathrm{r}}=1,1.10^{8} \mathrm{~L} /(\text { mol.s })
\end{array}
$$


$\mathrm{OH}$. can react eather way (eqs. 2.9 and 2.10):

$$
\begin{array}{cc}
\mathrm{OH}+\mathrm{O}_{3} & \rightarrow \mathrm{HO}_{4}, \\
\mathrm{HO}_{4} \cdot \rightarrow \mathrm{O}_{2}+\mathrm{HO}_{2}, & k_{\mathrm{r}}=2,0 \cdot 10^{9} \mathrm{~L} /(\mathrm{mol} . \mathrm{s}) \\
k_{\mathrm{r}}=2,8 \cdot 10^{4} / \mathrm{s}
\end{array}
$$

Following eq. 10 oxygen and $\mathrm{HO}_{2}$ are formed, and the reaction can begin again. The promoter is a compound which enables the transformation of $\mathrm{OH}$. into superoxide radical $\mathrm{O}_{2} \cdot{ }^{-} / \mathrm{HO}_{2}$, and catalyses the chain-reaction.

Organic molecules R are promoters. They contain functional groups and react with $\mathrm{OH}$. Organic radicals $\mathrm{R}$. are generated.

$$
\mathrm{H}_{2} \mathrm{R}+\mathrm{OH} \cdot \rightarrow \mathrm{HR}+\mathrm{H}_{2} \mathrm{O}
$$

Organic peroxide radical ROO is generated in the presence of oxygen and can react to form $\mathrm{O}_{2}{ }^{-} / \mathrm{HO}_{2}$. during chain-reaction:

$$
\begin{gathered}
\mathrm{HR} \cdot+\mathrm{O}_{2} \rightarrow \mathrm{HRO}_{2} . \\
\mathrm{HRO}_{2} \cdot \rightarrow \mathrm{R}+\mathrm{HO}_{2} . \\
\mathrm{HRO}_{2} \rightarrow \mathrm{RO}+\mathrm{OH} .
\end{gathered}
$$

\section{Reaction termination}

Compounds react with $\mathrm{OH}$ to produce radicals $\mathrm{O}_{2}{ }^{-} / \mathrm{HO}_{2}$. These are called inhibitors and terminate the reaction (eqs. 15 and 16). Known inhibitors are carbonate ions $\left(k=4,210^{8}\right.$ $\mathrm{L} /(\mathrm{mol} \mathrm{s}))$ and hydrogencarbonate ions $\left(k_{\mathrm{r}}=1,510^{7} \mathrm{~L} /(\mathrm{mol} \mathrm{s})\right), \mathrm{PO}_{4^{3-}}$, humic acids, and tertial butil alchohole $(\mathrm{t}-\mathrm{BuOH})$. There is a second method for terminating reaction when two radicals react to form oxygen and water (eq. 17).

$$
\begin{array}{ll}
\mathrm{OH}+\mathrm{CO}_{3}{ }^{2-} \rightarrow \mathrm{OH}^{-}+\mathrm{CO}_{3}{ }^{-}, & k_{\mathrm{r}}=\left(4,210^{8}\right) \mathrm{L} /(\mathrm{mol} \mathrm{s}) \\
\mathrm{OH}+\mathrm{HCO}_{3}{ }^{-} \rightarrow \mathrm{OH}^{-}+\mathrm{HCO}_{3} \cdot, & k_{\mathrm{r}}=\left(1,510^{7}\right) \mathrm{L} /(\mathrm{mol} \mathrm{s}) \\
\mathrm{OH}+\mathrm{HO}_{2} \rightarrow \mathrm{O}_{2}+\mathrm{H}_{2} \mathrm{O}, & k_{\mathrm{r}}=\left(3,710^{10}\right) \mathrm{L} /(\mathrm{mol} \mathrm{s})
\end{array}
$$

Two OH-radicals are formed per three molecules of ozone.

Other mechanisms are also possible. Some aromatic comounds with buffers decompose ozone within a system: aromatic ring $\Rightarrow$ olefine $\Rightarrow \mathrm{H}_{2} \mathrm{O}_{2} \Rightarrow \mathrm{HO}_{2}^{-}$. The aromatic ring reacts with hydroxyl radical or ozone, olefine is generated, and a chain is formed with two bonds $(\mathrm{C}-\mathrm{C}=\mathrm{C}-\mathrm{C}=\mathrm{C}-\mathrm{C})$. Olefine immediately reacts with ozone to form $\mathrm{H}_{2} \mathrm{O}_{2}$. A part of this molecule dissociates to $\mathrm{HO}_{2}{ }^{-}$, which accelerates ozone degradation. $\mathrm{t}$-butanole inhibits the aroomatic ring decay, and no $\mathrm{H}_{2} \mathrm{O}_{2}$ is formed. Some aromatic compaunds do not react with ozone but they do react with $\mathrm{OH}$-radical. This second pathway is faster than the mechanism explained above (Pi, 2005).

\section{Direct reactions}

The direct reaction of organic compounds with ozone is a selective process and the reaction rate constant $k_{\mathrm{r}}=1,0.10^{3} \mathrm{~L} /(\mathrm{mol} . \mathrm{s})$ is low (Gottschalk et al., 2000). It takes place when the radical mechanism is inhibited. Ozone reacts slowly with different organic compounds, 
whilest it reacts quickly with electron donors such as the hydroxyl group in phenole. Direct ozonation prevails if the radical mechanism is inhibited and if water contains terminating compounds. The direct mechanism is more important than the radical within $\mathrm{pH}$ ranges below 4 and vice-versa at higher $\mathrm{pH}$ above 10, while both mechansms are important within neutral range. Inorganic copmpounds, such as iron, manganesse, nitrite, cianide, bromide can be oxydized during ozonation. $\mathrm{Fe}^{2+}$ forms $\mathrm{Fe}(\mathrm{OH})_{3}, \mathrm{Mn}^{2+}$ forms $\mathrm{MnO}_{2}, \mathrm{NO}_{2}$ - forms $\mathrm{NO}_{3}-$ ions. The most problematic is the oxydation of bromide to bromate, which is a carcinogen. Certain chlorine by-products can be formed, such as $\mathrm{HOCl}, \mathrm{OCl}^{-}, \mathrm{ClO}_{2}^{-} \mathrm{v} \mathrm{ClO}_{3}^{-}$. However, more organics can be directly oxiydized by ozone.

\subsection{Micropollutants' oxidation with ozone}

Atrazine can be degraded by mechanisms involving dealkylation, deamination, dehalogenation, and hydroxylation. Atrazine degradation is $\mathrm{pH}$ and temperature dependent. The atrazine degradation efficiency was $17 \%$ at $\mathrm{pH} 3,3$, and was much higher up to $71 \%$ at $\mathrm{pH}=9,7$. If a higher $\mathrm{pH}$ value is applied more polar metabolites are formed and more atrazine is degraded (Kearney, 1988). Laboratory scale experiments showed that alkyl groups are oxydized, while amino alkyl groups are oxydized into acetamide. Ozonation of the N-ethyl group is five-times faster compared with ozonation of the Nisopropyl group (Hapeman, 1994). Two metabolites with imino-groups are formed. The Nethyl-group is more reactive compared with the $\mathrm{N}$-isopropyl group: 19-times by ozonation and 4-times by radical attack, therefore acetamide or imine is predominantly formed and does not react with ozone. The $\mathrm{N}$-isopropyl group forms a free amino-group following dealkylation. The major reaction products released during atrazine ozonation according to Acero (Acero et al., 2000), which are:

- Atrazine: 2-chloro-4-(ethylamino)-6-(isopropylamino)-s-triazine, (CIET, 67 \%)

- 4-acetamido-2-chloro-6-isopropylamino-s-triazine (CDIT, 24 \%),

- deisopropylatrazine: 2-amino-4-chloro-6-(ethylamino)-s-triazine (CEAT, 5 \%),

- deethylatrazine: 2-amino-4-chloro-6-(isopropylamino)-s-triazine (CIAT, 4 \%; four primary metabolites),

- 4-acetamido-6-amino-2-chloro-s-triazine (CDAT),

- 6-amino-2-chloro-4-ethylimino-s-triazine (CIAT-imine),

- deethyldeisopropylatrazine (DEDIA; three secundary metabolites).

Degradation of 2-kloro-4-ethylimino-6-isopropylamino-s-triazine using ozone is slow and the end products are unknown.

4-acetamido-2-chloro-6-isopropylamino-s-triazine is degraded by ozone to 4-acetamido-6-amino-2-chloro-s-triazine (100\%). Ozonation of deethylatrazine leads to deethyldeisopropylatrazine formation (100\%). Ozone attacks isopropyl groups and leads to dealkyilation of isopropyl group. Due to the ozonation of deisopropylatrazine 6-amino-2chloro-4-ethylimino-s-triazine (66 \%) and 4-acetamido-6-amino-2-chloro-s-triazine (34 $\%)$ are formed.

The dealkylation of 6-amino-2-chloro-4-ethylimino-s-triazine is very difficult to carry out. 4-acetamido-6-amino-2-chloro-s-triazine and deethyldeisopropylatrazine are the end products. 2-chloro-4-ethylimino-6-isopropylamino-s-triazine $(50 \%)$ is the major metabolite. Three products formed during the radical reactions plus a small portion of undefined products:

- 4-acetamido-2-chloro-6-isopropylamino-s-triazine, 
- 4-acetamido-6-amino-2-chloro-s-triazine

- 6-amino-2-chloro-4-ethylimino-s-triazine.

Oxydation of 4-acetamido-2-chloro-6-isopropylamino-s-triazine leads to

- 4-acetamido-2-hydroxi-4-isopropylamino-s-triazine (ODIT, $10 \%$ ) and

- 4-acetamido-6-amino-2-chloro-s-triazine (90 \%) formation.

While oxydation of deisopropylatrazine forms:

- 4-acetamido-6-amino-2-chloro-s-triazine (30\%) and

- 6-amino-2-chloro-4-ethylimino-s-triazine (70 \%).

Deethyldeisopropylatrazine and 4-acetamido-6-amino-2 -chloro-s-triazine are the end products. Hydrolisis of acetamide following dealkilation forms acetic acid. 4-acetamido-2-chloro-6-isopropylamino-s-triazine hydrolyses at $\mathrm{pH} \quad 6$ to 8 to deethyldeisopropylatrazine. The imino group hydrolyses to acetaldehide. Deethyilatrazine is also end-product (Acero et al, 2000).

Drinking water with atrazine at $190 \mathrm{~m}^{3} / \mathrm{d}$ flow was filtered and ozonized. The treated water contained increased concentrations of: deisopropylatrazine, deethylatrazine, deethyldeisopropylatrazine, hydroxydeethylatrazine 4-acetamido-2-chloro-6-ethylamino-striazine, hydroxydeisopropylatrazine, and other metabolites. (Verstraeten et al., 2002)

The ozone doze was $1,5 \mathrm{mg} / \mathrm{L}$, and the ozonation time $20 \mathrm{~min}$. After ozonation, the water was filtered. $2,2 \mathrm{mg} / \mathrm{L}$ of chlor $0,6 \mathrm{mg} / \mathrm{L}$ of fluor and $0,38 \mathrm{mg} / \mathrm{L} \mathrm{NH}_{4}{ }^{+}$were added before distribution to the city collection reservoir. The rate constants of $\mathrm{N}$-ethyl group ozonation were double that of $\mathrm{N}$-izopropyl group ozonation. Atrazine oxydation pathway was via $\mathrm{N}$-acethyl group and included $\mathrm{N}$-isopropyl group in smaller portion. Imine and amide were formed. The major reaction products released were (Verstraeten et al., 2002):

- deethylatrazine,

- deethyldeisopropylatrazine,

- 4-acetamido-2-chloro-6-etilamino-s-triazine (CDET),

- deisopropylatrazine,

while hydroxyatrazine (OIET; 2-(ethylamino)-4-hydroxy-6-(isopropylamino)-s-triazine) was not considered due to negligible dehalogenation. The $\mathrm{pH}$ of the water was above 8,5 , more deethylatrazine was formed in comparison with deisopropylatrazine. A similar process could be done with hydroxyatrazine where dealkyl products being formed (hydroxydeethylatrazine (OIAT; 2-amino-4-hydroxy-6-(isopropylamino)-s-triazine), and hydroxydeisopropylatrazine (OEAT; 2-amino-4-(ethylamino)-6-hydroxy -s-triazine (Verstraeten et al, 2002).

Ozonation alone is sometimes insufficient for successful oxidation of micropollutants. Ozone might be combined with other processes, such as UV-light, hydrogen peroxide, Fenton. The range of processes, termed advanced oxidation processes AOP' dosplayed great potential for treating organic micropollutants. Metabolites are formed during AOP, which could be even more toxic as target micropollutants. Therefore, ozonation is combined using filtration or adsorption.

\section{Advanced oxidation processes}

The range of AOP processes have been developed over the last 40 years in order to degrade organic micro-pollutants. AOPs are based on the generation of powerful oxidizing agents, especially hydroxy-radicals, which destroy micro-pollutants. The best-known is the direct 
photolysis of hydrogen peroxide and UV - direct photolysis or photo-induced processes, such as Photo-Fenton oxidation. Enhanced degradation of atrazine by ozonation is achieved by combining ozonation with other processes, such as $\mathrm{H}_{2} \mathrm{O}_{2}$ /ozone within the $\mathrm{pH}$ range above 7 (Meunier et al., 2006, Huang et al, 2004), and UV/ozone (Panno, 2004). Other combined processes are also known from the literature, such as $\mathrm{UV} / \mathrm{TiO}_{2}$ (Van Gunten, 2003), and UV/Fenton reagent (Hermanowicz et al, 1999). Chan \& Chu (Chan \& Chu, 2005) reported on the dependence of atrazine removal from concentration of dissolved iron ions, using Fenton reagent. Park (Park et al., 2004) proved the dependence of ozone decomposition on the $\mathrm{pH}$ of goethite surfaces during para-chlorobenzoic acid degradation. $\mathrm{Ni}$ (Ni et al., 2002) used different metal ions for 2-dichlorophenol degradation with ozone. $\mathrm{TiO}_{2} / \mathrm{hv} / \mathrm{O}_{2}$ is a powerful combination for pesticides degradation (Andreozzi et al, 1999). Compared to $\mathrm{OH}$ (1.8-2.7 V depending on the $\mathrm{pH}), \mathrm{SO}_{4}{ }^{-}$demonstrated higher standard reduction potential $(2.5-3.1 \mathrm{~V})$ at neutral $\mathrm{pH}$. At acidic $\mathrm{pH}$, they both demonstrated similar reduction potential, but $\mathrm{SO}_{4}{ }^{-}$, in general, was more selective for oxidizing organics than that of hydroxyl radicals. There were few studies on the generation mechanism of $\mathrm{SO}_{4}{ }^{-}$by cobalt- catalyzed decomposition in the homogeneous system. This $\mathrm{SO}_{4}{ }^{-}$radicals were very effective in oxidizing and transforming organic compounds like atrazine (Chan \& Chu, 2009).

\subsection{Ozone/Hydrogen peroxide}

$\mathrm{H}_{2} \mathrm{O}_{2}$ reacts with ozone as anion $\mathrm{HO}_{2}{ }^{-}$(Gottschalk et al., 2000). The reaction constant of the system $\mathrm{H}_{2} \mathrm{O}_{2} / \mathrm{O}_{3}$ depends on the initial oxydant's concentration. This reaction follows eqs. 18 and 21. The reaction of ozone and undisociiated $\mathrm{H}_{2} \mathrm{O}_{2}$ is also possible (see eq. 20), but the degradation rate is low. Initiation is also possible following eq.21 (Sunder \& Hempel, 1997).

$$
\mathrm{H}_{2} \mathrm{O}_{2} \leftrightarrow \mathrm{HO}_{2}^{-}+\mathrm{H}^{+}, \quad \mathrm{p} K_{\mathrm{a}}=11,8
$$

Iniciation of reaction:

$$
\begin{array}{cc}
\mathrm{HO}_{2}{ }^{-}+\mathrm{O}_{3} \rightarrow \mathrm{HO}_{2} \cdot \mathrm{O}_{3}{ }^{-}, & k_{\mathrm{r}}=2,2.10^{6} \mathrm{~L} /(\mathrm{mol} . \mathrm{s}) \\
\mathrm{H}_{2} \mathrm{O}_{2}+\mathrm{O}_{3} \rightarrow \mathrm{H}_{2} \mathrm{O}+\mathrm{O}_{2}, & k_{\mathrm{r}}<10^{-2} \mathrm{~L} /(\mathrm{mol} . \mathrm{s}) \\
\mathrm{H}^{+}+\mathrm{O}_{3} \rightarrow \mathrm{HO}_{3} \cdot \rightarrow \mathrm{HO}+\mathrm{O}_{2}, \quad k_{\mathrm{r}}=1,1.10^{5} / \mathrm{s}
\end{array}
$$

During the chain-reaction phase hydroxyl radicals are transformed into peroxy radicals (eqs. 22 to 24 ). $\mathrm{pK}$ a for $\mathrm{O}_{2}{ }^{-} / \mathrm{HO}_{2}$ is 4,8 (see eq. 5), and radical chain-reaction ends following eq 6 . Compounds in water can act as promoters or scavengers, such as organic pollutants. The radical chain-reaction goes as follows (Sunder \& Hempel, 1997):

$$
\begin{array}{ll}
\mathrm{HO} \cdot+\mathrm{O}_{3} \rightarrow \mathrm{HO}_{2}+\mathrm{O}_{2,} & k_{\mathrm{r}}=1,1.10^{8} \mathrm{~L} /(\mathrm{mol} . \mathrm{s}) \\
\mathrm{H}_{2} \mathrm{O}_{2}+\mathrm{HO} \cdot \rightarrow \mathrm{H}_{2} \mathrm{O}+\mathrm{HO}_{2}, & k_{\mathrm{r}}=2,7.10^{7} \mathrm{~L} /(\mathrm{mol} . \mathrm{s}) \\
\mathrm{HO}+{ }^{+}+\mathrm{HO}_{2} \cdot \rightarrow \mathrm{H}_{2} \mathrm{O}+\mathrm{O}_{2}{ }^{-}, & k_{\mathrm{r}}=7,5.10^{9} \mathrm{~L} /(\mathrm{mol} . \mathrm{s})
\end{array}
$$

An electron pathway from $\mathrm{H}_{2} \mathrm{O}_{2}$ to $\mathrm{HO}_{2}{ }^{-}$or bimolecular degradation is possible. During the ozonation of perchloroethene inorganic carbon acts as a hydroxyl radical scavenger and is formed due to the addition of $\mathrm{H}_{2} \mathrm{O}_{2}$. Increased concentration of inorganic carbon in water 
caused lower pollutant concentration. Free radicals are un-available due to the reaction with ozone, the ozone degradtaion decreases, and the concentration of inorganic carbon affects ozone stabilization. This effect is impossible at high $\mathrm{pH}$. Most of the inorganic carbon is in hydrogencarbonate ion form at $\mathrm{pH}=7$. The inorganic carbon concentration was between 50 and $200 \mathrm{mg} / \mathrm{L}$ and consequently alkalynity was high. Hydrogencarbonate ions react with hydroxyl radicals at a lower constant rate of 8,5.106 L/(mol. s) (Acero \& Von Gunten, 1998) compared with atrazine and nitrobenzene with $k=3.10^{9} \mathrm{~L} /(\mathrm{mol} . \mathrm{s})$ (Hoigne, 1997). Due to a higher concentration of hydrogencarbonate compared with organic pollutants it can be presumed that hydrogencarbonate consumes hydroxyl radicals. The inhibitory effect of hydrogen-carbonate is formed originating from the reaction with hydroxyl and hydrogencarbonate radicals which act selectively. They also express a lower reaction constant compared with hydroxyl radicals for the oxidation of organic pollutants (Hoigne, 1998). The reaction of hydrogencarbonate and hydroxyl radicals leads to intermediate formation, which can enable the radicals to form (Legube et al., 2004).

Termination phase:

The reaction between hydroxyl radicals and inorganic carbon produces carbonate radical $\mathrm{CO}_{3}{ }^{-}$, and the reaction mechanism is insufficiently established in the literature (eqs. 25 to 27 ).

$$
\begin{gathered}
\mathrm{HO}+\mathrm{HCO}_{3}{ }^{-} \rightarrow \mathrm{H}_{2} \mathrm{O}+\mathrm{CO}_{3}{ }^{-}, \\
k_{\mathrm{r}}=1,5.10^{7} \mathrm{~L} /(\mathrm{mol} \mathrm{s}) \\
\left(\text { Rosenfeldt et al., 2006), 8,5. } 10^{6} \mathrm{~L} /(\mathrm{mol} . \mathrm{s})(\mathrm{Ma}, 2000)\right. \\
\mathrm{HO}+\mathrm{CO}_{3}{ }^{-} \rightarrow \mathrm{HO}^{-}+\mathrm{CO}_{3}{ }^{-}, \\
k_{\mathrm{r}}=4,210^{8} \mathrm{~L} /(\mathrm{mol} \mathrm{s})(\text { Rosenfeldt et al., 2006), 3,9.108 } \mathrm{L} /(\text { mol.s })(\mathrm{Ma}, 2000) \\
\mathrm{HO}+\text { pollutant } \rightarrow \mathrm{H}_{2} \mathrm{O}+\mathrm{CO}_{2}+\text { products }
\end{gathered}
$$

The reaction constant for $\mathrm{HO}_{2}^{-}$was determined at 2,2.106 $\mathrm{L} /\left(\right.$ mol.s) and for $\mathrm{HO}^{-}$at 70 $\mathrm{L} /$ (mol.s). The latter is negligible in comparison with the first.

The constant for atrazine degradation in the presence of hydroxyl radicals was determined at:

- $k_{\mathrm{r}}=3.10^{9} \mathrm{~L} /($ mol.s) at $\mathrm{pH}=2$ (Accero et al, 2000),

- $k_{\mathrm{r}}=2,4.10^{9} \mathrm{~L} /($ mol.s $)$ at $\mathrm{pH}=2$ (DeLaat et al, 1994),

- $\quad k_{\mathrm{r}}=2,6.10^{9} \mathrm{~L} /($ mol.s) at $\mathrm{pH}=3.6$ (photo-Fenton) (Haag \& Yao, 1992).

The direct constant of atrazine decomposition was calculated at:

- $k_{\mathrm{r}}=7,90 \pm 0,62 \mathrm{~L} /\left(\right.$ mol.s) at $\mathrm{pH}=3$ and $25 \pm 0,2{ }^{\circ} \mathrm{C}$ (Camel \& Bermont, 1998), which is very low.

Two end products are formed if atrazine is exposed to the $\mathrm{H}_{2} \mathrm{O}_{2} / \mathrm{O}_{3}$ process, 2,4-diamino-6-hydroxy-s-triazine at $\mathrm{pH}=8$ and deethyldeisopropylatrazine. The share of both compounds depends on hydroxyl radical concentration (Nelieu et al., 2000).

The $\mathrm{H}_{2} \mathrm{O}_{2} / \mathrm{O}_{3}$ process is advisable for oxidation in water if the ozone molecule is relatively stable (Acero \& von Gunten, 2001). Such waters do not contain many organic substances but the alkalinity is high. During ground-water ozonation, the ozone reacts quickly during the initial phase, then the first-order reaction takes place. Sometimes we can not differentiate between these two phases due to the very rapid end of the first one. During the $\mathrm{H}_{2} \mathrm{O}_{2} / \mathrm{O}_{3}$ process only one phase was obseved for both types of drinking water. The ozone degradation rate constant was 10- times lower compared with the $\mathrm{H}_{2} \mathrm{O}_{2} / \mathrm{O}_{3}$ process, in 
ground-water, while twice as low in surface water. The quantity of hydroxyl radicals was measured by $\mathrm{p}$-chlorobenzoic acid transformation. It reacted with hydroxyl radicals at $k_{\mathrm{r}}=$ 5,2. $10^{9} \mathrm{~L} /$ (mol. s) and not with ozone, due to the very low constant $k_{\mathrm{r}}=0,15 \mathrm{~L} /$ (mol.s). One hydroxyl radical per three molecules of ozone is formed during ozonation while one hydroxyl radical per one molecule of ozone is formed during the $\mathrm{H}_{2} \mathrm{O}_{2} / \mathrm{O}_{3}$ process in pure water, which means $2 / 3$ of the hydroxyl radicals during $\mathrm{H}_{2} \mathrm{O}_{2} / \mathrm{O}_{3}$ are formed due to ozonation during the initiation phase. Hydroxyl radicals' formation per ozone molecule is 0,5 in real water samples. The formation of hydroxyl radicals increased from 23 to $54 \%$ during ozonation and the $\mathrm{H}_{2} \mathrm{O}_{2} / \mathrm{O}_{3}$ process in ground-water. In the surface-water, the formation of hydroxyl radicals was comparable with the ozonation and $\mathrm{H}_{2} \mathrm{O}_{2} / \mathrm{O}_{3}$ processes. The surface-water contained more NOM, which acted as a hydroxyl radicals' promoters; one hydroxyl radical formed per one molecule of ozone (theoretical value for $\mathrm{OH} / \mathrm{O}_{3}$ was the same as for $\mathrm{O}_{3} / \mathrm{H}_{2} \mathrm{O}_{2}$ ). The addition of $\mathrm{H}_{2} \mathrm{O}_{2}$ did not significantly accelerate the ozone degradation. The alkalinity of the surface-water was higher than that of the ground-water, therefore, the $\mathrm{p}$-chlorobenzoic acid degradation rate was higher in groundwater. Namely, the inorganic carbon species are scavengers of hydroxyl radicals. Atrazine was decomposed in 300 min during ozone oxidation, and in 80 mins during the $\mathrm{H}_{2} \mathrm{O}_{2} / \mathrm{O}_{3}$ process (Acero \& von Gunten, 2001).

\subsection{Ozone/UV}

The degradation of organic compounds takes place by photolysis (Beltran, 1996). Ozone in water is decomposed into $\mathrm{H}_{2} \mathrm{O}_{2}$ (eq. 28). Ultraviolet lights should expose photolysis at $254 \mathrm{~nm}$.

$$
\mathrm{O}_{3}+\mathrm{H}_{2} \mathrm{O} \rightarrow \mathrm{H}_{2} \mathrm{O}_{2}+\mathrm{O}_{2}
$$

Oxidation of the compound can be achieved by each oxidant: UV-radiation, ozone, and $\mathrm{H}_{2} \mathrm{O}_{2}$. Direct photolysis of UV-light absorption can take place. Direct oxydation by $\mathrm{H}_{2} \mathrm{O}_{2}$ is impossible under normal conditions at $\mathrm{pH}=5-10$ and room temperature. The extinction coeficient $\varepsilon$ for ozone at $254 \mathrm{~nm}$ is higher $(\varepsilon=3300 \mathrm{~L} /($ mol.cm $))$ comapred with $\mathrm{H}_{2} \mathrm{O}_{2}(\varepsilon=$ $18,6 \mathrm{~L} /(\mathrm{mol} . \mathrm{cm}))$. The rate of ozone degradation is 1000 -higher compared with $\mathrm{H}_{2} \mathrm{O}_{2}$ degradation (Gottschalk et al., 2000).

During ozonation, the ozonide radical ion $\mathrm{O}_{3}{ }^{-}$is formed from $\mathrm{O}^{-}$and $\mathrm{O}_{2}$. If $\mathrm{O}^{-}$are absent, $\mathrm{O}_{3}{ }^{-}$degrade to $\mathrm{O}^{-}$and $\mathrm{O}_{2}$, and reacts with $\mathrm{O}^{-} . \mathrm{O}_{3}{ }^{-}$degradation is very sensitive to $\mathrm{O}^{-}$ presence. $\mathrm{O}_{3}{ }^{-}$are generated with photolysis alkaline water $(\mathrm{pH}>12,7)$ and $\mathrm{H}_{2} \mathrm{O}_{2}$ or $\mathrm{S}_{2} \mathrm{O}_{8}{ }^{2-}$ addition. The first order reaction takes place with $\mathrm{H}_{2} \mathrm{O}_{2}$, whilest then using $\mathrm{S}_{2} \mathrm{O}_{8}{ }^{2-}$ a more complex degradation process take palce and more intermediates are formed (Gonzales\&Martire, 1997).

The fluorescence method was introduced to analyze hydroxyl radical levels during indirect ozone process, and $\mathrm{O}_{3} / \mathrm{UV}$ processes. It was observed that the amount of hydroxyl radical exposure during the $\mathrm{O}_{3} / \mathrm{UV}$ process was much higher than in the indirect ozone process. If the alkalinity in water is high, the inhibition is significant and the linear correlation between alkalinity and hydroxyl radical exposure was revealed which might have insight into the effect of alkalinity on the inhibition of hydroxyl radicals. Consequently, more reduction of TOC and DBP during the $\mathrm{O}_{3} / \mathrm{UV}$ process would be observed. 
The chlorine demand increases with decreasing $\mathrm{pH}$ and increasing alkalinity. It could be concluded that hydroxyl radical can more strongly destroy the organic precursors resulting in reducing chlorine consumption than an ozone molecule (Gonzales \& Martire, 1997).

\subsection{UV/Hydrogen peroxide}

Degradation of organic compounds can take place if the light energy is adsorbed by the molecule to produce an electronically-excited molecular state, and chemical transformation is competitive with deactivation process. $\mathrm{UV} / \mathrm{H}_{2} \mathrm{O}_{2}$ generally involves the generation of hydroxyl radicals' formation. The photolysis of $\mathrm{H}_{2} \mathrm{O}_{2}$ yields two hydroxyl radicals formed per photon, absorbed by $254 \mathrm{~nm}$ during a direct process (eq. 29). $\mathrm{HO}_{2}{ }^{-}$also absorbs energy by $254 \mathrm{~nm}$ and is in acid-base equilibrium with $\mathrm{H}_{2} \mathrm{O}_{2}$ (eqs. 30 and 31) (Gottschalk et al., 2000).

$$
\begin{array}{lrl}
\mathrm{H}_{2} \mathrm{O}_{2} \rightarrow 2 \mathrm{OH}, & \varepsilon=18,6 \mathrm{~L} / \text { (mol.s) } \\
\mathrm{HO}_{2}{ }^{-} \rightarrow \mathrm{OH} \cdot+\mathrm{O}^{-}, & \varepsilon=240 \mathrm{~L} / \text { (mol.s) } \\
\mathrm{HO}_{2}{ }^{-}+\mathrm{O}^{-} \rightarrow \mathrm{OH}^{-}+\mathrm{O}_{2}{ }^{-}, & k_{\mathrm{r}}=4.10^{8} \mathrm{~L} / \text { (mol.s) }
\end{array}
$$

Prado (Prado \& Esplugas, 1999) studied atrazine degradation using UV light at different $\mathrm{pH}$ values $4,74,6,85$ and 11,71 . The best results were achieved at $\mathrm{pH} 11,71$ over $50 \mathrm{~min}$. In a second set of experiments, atrazine was treated with $\mathrm{H}_{2} \mathrm{O}_{2} .4 \%$ of atrazine was oxidized at $\mathrm{pH}=4,8,9 \%$ at $\mathrm{pH}=6,8$, and total atrazine degradation was achieved within $240 \mathrm{~min}$ at $\mathrm{pH}=11,4$. Enough radicals were available at a high $\mathrm{pH}$ without UV-irradiation. Atrazine was oxidized with ozone and $50 \%$ of atrazine decomposed within $90 \mathrm{~min}$ at $\mathrm{pH}=4,74$, while $70 \%$ at $\mathrm{pH}=6,88$ and again total degradation was achieved at high $\mathrm{pH}$ 11,55 within 30 mins. It can be conceluded from the results, that direct ozonation is slower compared with the radical. During indirect reaction a lot of hydroxyl radicals were formed at high $\mathrm{pH}$ values. The $\mathrm{UV} / \mathrm{H}_{2} \mathrm{O}_{2}$ process was studied for atrazine removal. Within the neutral $\mathrm{pH}$ range only 15 min was needed for atrazine removal, whilest when using UV 50 min was necessary. The atrazine disappeared at $\mathrm{pH}=4,74 \mathrm{in} 25 \mathrm{~min}$. The process is slower compared with the use of $\mathrm{UV}$ at only $\mathrm{pH}=11,55$. Other reactions take place at higher $\mathrm{pH}$ values and the hydroxyl radical formation is deactivated. At $\mathrm{O}_{3} / \mathrm{UV}$ process, $\mathrm{H}_{2} \mathrm{O}_{2}$ decomposes to hydroxyl radicals just like the $\mathrm{H}_{2} \mathrm{O}_{2} / \mathrm{UV}$ process. Atrazine decomposes within $80 \mathrm{~min}$ at $\mathrm{pH}$ $=4,65$, within 40 mins at $\mathrm{pH}=7,2$, and within 30 mins at $\mathrm{pH}=11,23$. During the $\mathrm{O}_{3} / \mathrm{H}_{2} \mathrm{O}_{2}$ process, $70 \%$ of atrazine decomposes within 90 mins at $\mathrm{pH}=4,0$, total degradation takes place within 40 mins at $\mathrm{pH}=6,92$, and within 30 mins at $\mathrm{pH}=10,1$. In this study $\mathrm{H}_{2} \mathrm{O}_{2}$ concentration was 10 -times higher than stechioometric concentration. The $\mathrm{O}_{3} / \mathrm{H}_{2} \mathrm{O}_{2} / \mathrm{UV}$ process showed that atrazine decomposes within 30 mins at $\mathrm{pH}=4,31 t=30 \mathrm{~min}$, within 15 mins at $\mathrm{pH}=6,7$, and within 100 mins at $\mathrm{pH}=11,03$. The best results were achieved using $\mathrm{UV} / \mathrm{H}_{2} \mathrm{O}_{2}$ at $\mathrm{pH}=6,8$ followed by $\mathrm{O}_{3} / \mathrm{H}_{2} \mathrm{O}_{2} / \mathrm{UV}$ within the neutral $\mathrm{pH}$ range. The half-life times for atrazine degradation are listed in Table 1 . The concentration of atrazine was 6,95. $10^{-5} \mathrm{~mol} / \mathrm{L}$ at the temperature $20-23^{\circ} \mathrm{C}$. (Prado \& Esplugas, 1999).

Atrazine was degraded in ultra-pure water. The best results were achieved using $\mathrm{O}_{3} / \mathrm{UV}$ which is in accordance with other experiments. The water type has a major influence on removal efficiency (Beltran et al., 2000). 


\begin{tabular}{|c|c|c|c|}
\hline $\mathrm{pH}$ & $(4,3-4,8)$ & $(6,7-7,2)$ & $(10,1-11,7)$ \\
\hline process & $t / \mathrm{min}$ & $t / \mathrm{min}$ & $t / \mathrm{min}$ \\
\hline $\mathrm{UV}$ & 9,7 & 8,2 & 7,1 \\
\hline $\mathrm{O}_{3}$ & 81 & 38 & 3,6 \\
\hline $\mathrm{H}_{2} \mathrm{O}_{2}$ & $/$ & $/$ & 32 \\
\hline $\mathrm{H}_{2} \mathrm{O}_{2} / \mathrm{UV}$ & 4,7 & 2,2 & 25,4 \\
\hline $\mathrm{O}_{3} / \mathrm{UV}$ & 14 & 9 & 8,5 \\
\hline $\mathrm{O}_{3} / \mathrm{H}_{2} \mathrm{O}_{2}$ & 52 & 10 & 16 \\
\hline $\mathrm{O}_{3} / \mathrm{H}_{2} \mathrm{O}_{2} / \mathrm{UV}$ & 4,9 & 3,1 & 20 \\
\hline
\end{tabular}

Table 1. The half-life time of atrazine

\subsection{Ozone/Metal catalyst}

Catalytic ozonation is a new technology developed over recent years. It was discovered, that the reaction rate increased when $\mathrm{Pb}^{2+}, \mathrm{Cu}^{2+}, \mathrm{Zn}^{2+}, \mathrm{Fe}^{2+}, \mathrm{Ti}^{2+}$, and $\mathrm{Mn}^{2+}$ ion were applied during the ozonation of 2-dichlorophenol ( $\mathrm{Ni}$ et al., 2002).

The best results were achieved using $\mathrm{Mn}^{2+}\left(k_{\mathrm{r}}=227 \mathrm{~L} /(\right.$ mol.min $\left.)\right)$ followed by Fe ${ }^{2+}\left(k_{\mathrm{r}}=143\right.$ $\mathrm{L} /($ mol.min $)$, , $\mathrm{Ti}^{2+}$ with $k_{\mathrm{r}}=139 \mathrm{~L} /(\mathrm{mol} . \mathrm{min}), \mathrm{Zn}\left(k_{\mathrm{r}}=107 \mathrm{~L} /(\mathrm{mol} . \mathrm{min}), \mathrm{Cu} k_{\mathrm{r}}=89\right.$ $\mathrm{L} /\left(\right.$ mol.min) and $\mathrm{Pb} k_{\mathrm{r}}=81 \mathrm{~L} /(\mathrm{mol} . \mathrm{min})$. The reaction rate was three time higher at $\mathrm{pH}=3$ and $1 \mathrm{mg} / \mathrm{L} \mathrm{Mn}^{2+}$ in comprarison with treatment without $\mathrm{Mn}$. With an initial Mnconcentration of 0 to $2 \mathrm{ppm}$, after gas exposure for $20 \mathrm{~min}$ the removal rate can be increased from $38 \%$ to $93 \%$. The TOC removal rate increased from $13 \%$ to $38 \%$ over $60 \mathrm{~min}$. The reaction rate improved greatly at an initial $\mathrm{pH}=3$. Linear correlation was established between ozone degradation with a metal catalyst, and the oxydation abilities of pollutants. At high $\mathrm{pH}$ values atrazine degradation is high due to high concentrations of $\mathrm{OH}$-radicals (Ni et al., 2002). Manganesse is non-toxic to humans. The maximum allowable concentration (MAC) of $50 \mu \mathrm{g} / \mathrm{L}$ was set for $\mathrm{Mn}^{2+}$. Linear correlation was established between $\mathrm{Mn}^{2+}$ concentration and concentration of undecomposed atrazine in dependence of time. The catalytical ability of $\mathrm{Mn}^{2+}$ activation was higher than that of the $\mathrm{Mn}^{4+}$ ions created after the reaction of $\mathrm{KMnO}_{4}$ and $\mathrm{MnSO}_{4}$. Comercially-available $\mathrm{MnO}_{2}$ proves the non-degradation ability of atrazine. The authors explained that fact by the formation of hydroxyl radicals if $\mathrm{Mn}^{2+}$ is combined with ozone generation. If the $\mathrm{Mn}^{2+}$ concentration was higher, more ozone reacted with the organic pollutant and less ozone remained in the solution. Even the flowrate of ozone from the air-gas into the solution was higher with higher manganesse ions in the solution. If the $\mathrm{Mn}^{2+}$ concentration was $1.5 \mathrm{~g} / \mathrm{L} 65 \%$ of ozone flows from air and only 35 $\%$ without $\mathrm{Mn}^{2+}$ (Ma \& Graham, 1997). The humic acid influence on atrazine degradation was studied by the same authors. At a low quantity of humic acids at $1 \mathrm{mg} / \mathrm{L}$ the degradation process was accelerated with the presence of $\mathrm{Mn}^{2+}$ or $\mathrm{MnO}_{2}$, due to the humic acids acting as initiators and promoters of radical reaction. At higher humic acid concentrations $(2,4$ and $6 \mathrm{mg} / \mathrm{L})$ the process of atrazine degradation was inhibited by the humic acids despite different additions of $\mathrm{Mn}^{2+}$ or $\mathrm{MnO}_{2}$, due to the reaction of humic acid with hydroxyl radicals. $\mathrm{MnO}_{2}$ exhibits certain adsorption properties for certain pollutants, therefore the theory of atrazine adsorption onto $\mathrm{MnO}_{2}$ was experimentally proven. The results show that only $10 \%$ of atrazine adsorbed onto $\mathrm{MnO}_{2}$ which is low, regardless on the concentration of humic acid in the solution (Ma \& Graham, 1999). In the same reasearch, the 
effect of hydrogencarbonate and t-butanole on atrazine ozonation was studied and using catalyst $\mathrm{Mn}^{2+}$. $\mathrm{Mn}^{2+}$ improved the atrazine degradation. Polar low molecular weight metabolites were formed. Increased hydrogencarbonate ion concentrations or t-butanole decreased the atrazine degradation rate, because they acted as $\mathrm{OH}$-radical scavengers. The worst results were achieved with t-butanole, which reacts with hydroxyl radicals at a rate of $5 \cdot 10^{8} \mathrm{~L} /(\mathrm{mol} . \mathrm{s})$, and is faster compared with hydrogencarbonate ions. Inert intermediates are formed during t-butanole reaction with hydroxyl radicals, which terminate the reaction, and with t-butanole acting as the inhibitor. Ozone degradation is slower even at low tbutanole concentrations of $5 \mathrm{mg} / \mathrm{L}$ (Ma \& Graham, 2000).

p-chlorobenzoic acid was exposed to ozonation using goethite $(\mathrm{FeOOH})$, with particle sizes $0,3-0,6 \mathrm{~mm}$, and a specific area of $147 \mathrm{~m}^{2} / \mathrm{g}$. The ozone rate constants were double using 2 $\mathrm{g} / \mathrm{L} \mathrm{FeOOH}$ compared with ozonation alone (Park, 2004).

Simazine, atrazine (ethyl and isopropyl groups), and terbuthylazide (ethyl and t-buthyl groups) at $\mathrm{pH}=3$ were oxidized by ozone, as well as $\mathrm{Ce}\left(\mathrm{NH}_{4}\right)_{2}\left(\mathrm{NO}_{3}\right)_{6}$ in acetonitrile. Dealkyilation of the N-ethyl group took place, whilest it was negligible for atrazine. Dealkylation of t-buthyl group did not appear, therefore $\mathrm{N}$-deethylation dominated. The ratio $\mathrm{N}$-deethylation/ $\mathrm{N}$-deisopropylation was determined at 11,5 using $\mathrm{Ce}\left(\mathrm{NH}_{4}\right)_{2}\left(\mathrm{NO}_{3}\right)_{6}$ whilest it was 5,3 using ozone. Oxidative N-dealkylation of small linear alkyl groups is faster if alkyl chained groups are larger at chemical oxidants, and in enzimatic systems. Ozonation of atrazine and terbuthylazide generated traces of amides during oxidation of carbon next to nitrogen on N-ethyl group (Bolzacchini et al., 1994).

The atrazine ring opens using $\mathrm{Al}_{2} \mathrm{O}_{3}$ from 240 to $450{ }^{\circ} \mathrm{C}$. Triazine ring hydrolises to amonium and carbon dioxide. Those groups which are bonded to the triazine ring reacted with hydrogen to form small molecules (Zhan et al., 1996).

Kinetic decomposition of ozone and atrazine (and its metabolites), were studied using ozonation and catalytic ozonation. Three different types of Pt-catalyst were applied by studying the atrazine decay-rate. It was found that the addition of Pt-catalyst improves the atrazine decay rate at higher $\mathrm{pH}$. The improvement was more significant using $\mathrm{Dohr}_{1}-\mathrm{Pt}$ catalyst. After $30 \mathrm{~min}$ of catalytic ozonation, up to $93 \%$ of atrazine was removed, whilest only $33 \%$ of atrazine was removed after $30 \mathrm{~min}$ of ozonation without the catalyst. HPLC analyses showed that atrazine did not decompose to form deethylatrazine, but some other substances which could not be detected using our analytical methods. Pt-catalysts increased the ozone decomposition rate. The determined rate constants using ozonation with Ptcatalyst were twice the values of ozonation without catalyst. The ozone decomposition was generated in the bulk solution and on the surface of the Pt-catalyst. The highest rate of decomposition in the bulk solution was achieved within the $\mathrm{pH}$ range above 7 , and was equal to $0.02621 / \mathrm{min}$; on the catalyst surface the highest decomposition rate of 0.0120 $1 /$ min.g L was achieved in a neutral $\mathrm{pH}$. The decomposition of ozone is proportional to the Pt catalyst mass (Tepuš \& Simonič, 2007; Tepuš \& Simonič, 2008).

\subsection{UV/Metal catalyst}

Pesticides could be degraded using high pressure mercury or xennon light due to different photochemicall processes. Long reaction times and highly energetic photones are needed. Pesticides are often incompletely removed. The major reactions using UV-light are dehalogenation, substitution of chloride atom by hydroxil groups, and radical formation advanced oxidation processes with UV-light are promising processes for pesticide degradation. Ther is a difference between: 
- $\quad$ homogenous $\left(\mathrm{H}_{2} \mathrm{O}_{2} / \mathrm{UV}, \mathrm{Fe}^{3+} / \mathrm{UV}\right)$ and

- heterogenous photocatalitic processes $\left(\mathrm{TiO}_{2} / \mathrm{UV}, \mathrm{ZnO}_{2} / \mathrm{UV}\right)$.

Photocatalitic advanced oxidation processes are light-induced reactions based on hydroxil radicals' formation in combination with oxidants, such as $\mathrm{TiO}_{2}, \mathrm{ZnO}_{2}$, Fenton. Titan dioxide $\left(\mathrm{TiO}_{2}\right)$ is a more frequently used photocatalyst for pesticide degradation. Light is absorbed at $\lambda<385 \mathrm{~nm}$ (while $\mathrm{H}_{2} \mathrm{O}_{2} / \mathrm{UV}$ needs $\lambda$ between 210 and $230 \mathrm{~nm}$ ). Positive sites in the net are generated acting as strong oxidants, or hydroxil radicals are formed. $\mathrm{TiO}_{2}$ uses sun-light as an energy source. If the catalyst is bonded to the surface, the efficiency is lower in comparison with those processes where $\mathrm{TiO}_{2}$ ions are mixed into the solution. If $\mathrm{TiO}_{2}$ is bonded to the activated carbon, the pesticide reaction rate might increase and the generation of atrazine metabolites decrease. For $90 \%$ atrazine degradation 9,1 min was necessary during the $\mathrm{TiO}_{2} / \mathrm{UV}$ process, 9,2 min for ozonation, and below 0,5 min using $\mathrm{Fe} / \mathrm{UV}$ (Chiron, 2000).

Atrazine degradation using UV light and $\mathrm{TiO}_{2}$ catalyst was studied (Pelizzetti, 1992). Hydrolisys of 2-chloro substituent on a ring took place, oxidation of alkyln group, and dealkylation and deamination of the chain. Finally, the amino groups were replaced by hydroxil ones. A series of intermediates were analysed, while the cianuric acid did not decompose. Atrazine decomposition was fast, whilest the cianuric acid rate was slow due to the amino group bonding to the triazine ring replacement by hydroxil ones. Inorganic compounds, such as peroxodisulphate accelerate cianuric acid formation. Many products are generated with high hydrofilicity, and are less toxic.

$95 \%$ of atrazine was degraded photocatalytically on immobilised $\mathrm{TiO}_{2}$ at $\mathrm{pH}=7,1$ with the initial concentration of atrazine at $1 \mathrm{mg} / \mathrm{L}$, over $24 \mathrm{~h}$. When real water was used as matrix, the atrazine degradation rate was reduced at a factor of 3. Orto-phosphate and carbonate ions slightly improved the process, whilest other inorganic species did not influence the reaction rate. Atrazine in destilated water decomposes into deethylatrazine, deisopropylatrazine, hydroxiatrazine, deethyldeisopropylatrazine, deethylhydroxiatrazine (OIAT), deisopropylhydroxiatrazine (OEAT), deethyldeisopropylhydroxiatrazine (OAAT). The latter decomposes into cianuric acid (OOOT). In drinking-water atrazine decomposes into deethylatrazine, deisopropylatrazine and deethyldeisopropylatrazine. Photochemical degradation yields dehalogenated products, while photocatalytical degradation yields dealkilated products (Ziegmann et al., 2006).

\subsection{Hydrogen peroxide/metal catalyst}

Fenton reagent $\left(\mathrm{H}_{2} \mathrm{O}_{2}\right.$ and $\left.\mathrm{Fe}^{2+}\right)$ enables hydroxil radicals formation following eqs. 32 and 33 .

$$
\begin{gathered}
\mathrm{Fe}^{2+}+\mathrm{H}_{2} \mathrm{O}_{2} \rightarrow \mathrm{Fe}^{3+}+\mathrm{HO}+\mathrm{HO}^{-} \\
\mathrm{HO}+\mathrm{Fe}^{2+} \rightarrow \mathrm{HO}^{-}+\mathrm{Fe}^{3+}
\end{gathered}
$$

Oxidation of alkylamino groups and/or dealkylation take palce. The exact mechanism is unknown, as yet.

Atrazine was degraded into:

- 4-acetamido-2-chloro-6-isopropylamino-s-triazine,

- deethylatrazine,

- 4-acetamido-2-chloro-6-ethylamino-s-triazine (CDET), 
- deisopropylatrazine,

- 4-acetamido-2-hydroxi-6-isopropilamino-s-triazine, due to dehalogenation, oxidation of alkyl groups. In less than 30 s out of atrazine:

- deethyldeisopropylatrazine $(23 \%)$ and

- 4-acetamido-6-amino-2-chloro-s-triazine (28 \%) were formed.

Higher Fenton reagent concentrations enables the formation of 4-acetamido-6-amino-2-chloro-s-triazine, and deethyldeisopropylatrazine. The endproduct was 2, 4-diamino-6-hydroxy-s-triazine. The efficiency of atrazine degradation was $99 \%$ at $\mathrm{pH}=3$, and only $37 \%$ at $\mathrm{pH}=9$ (Arnold et al., 1995).

The next study suggest two phases of atrazine decomposition: 'faster and slower 'following second order kinetics (Chan \& Chu, 2003), more metabolites were analysed:

- 2-chloro-4-(1-carboxylethanolamino)-6-isopropylamino-s-triazine

(CIET-carboxylethanolamino),

- 2-hydroxy-4-acetamido-6-ethylamino-s-triazine (ODET),

- 6-hydroy-4-ethylamino-2-amino-s-triazine,

- 4-hydroxy-6-isopropylamino-2-amino-s-triazine (Chan \& Chu, 2005)

Fenton reagent consists of an iron salt which is usually Fe- sulphate. In this study, iron hydride within an anaerobic environment was used, due to the fact that oxygen leads to organic radicals' formation and peroxyl radicals, which affect the $\mathrm{Fe}^{2+}$ and hydroxyl radical concentrations, but not the reaction rate of atrazine degradation. Therefore, secondary reactions do not affect rate reaction. The constant reaction rate using iron hidride was ten times higher at $\mathrm{pH}=3$ than at $\mathrm{pH}=8$ (Barreiro et al., 2007).

Reaction rate constants were determined at $0,24-2,83.10^{3} 1 / \mathrm{s}$ for atrazine and (1,57-12,75).105 1 /s for $\mathrm{H}_{2} \mathrm{O}_{2}$ using $\mathrm{Fe}^{3+} / \mathrm{H}_{2} \mathrm{O}_{2}$ for $80 \%$ atrazine removal in 1 h. Higher $\mathrm{H}_{2} \mathrm{O}_{2}$ led to higher rate constants til the certain value and after that they decrease (Gallard \& De Laat, 2000).

Continuously electrogenerating of $\mathrm{H}_{2} \mathrm{O}_{2}$ from the electro-reduction of dissolved $\mathrm{O}_{2}$ and combination of $\mathrm{Fe}^{3+}$ and $\mathrm{Cu}^{2+}$ leads to the optimum degradation rate for which complete disaperance of atrazine is achivied at $22 \mathrm{~min}$. However, $\mathrm{Cu}^{2+}$ concentrations higher than 10 $\mathrm{mM}$ inhibit $\mathrm{H}_{2} \mathrm{O}_{2}$ generation and consequently atrazine degradation rate because of copper deposition on the carbon- felt cathode surface. In this study degradation of cyanuronic acid, the ulitmate product of atrazine was observed, which is very rare (Balci et al., 2009).

\section{Adsorption media for atrazine removal}

\subsection{Adsorption isotherms}

Adsorption isotherms are developed by exposing a given amount of adsorbate in a fixed volume of liquid to varying amounts of activated carbon. The adsorbent phase after equlibrium is calculated using eq. 34 :

$$
c_{\mathrm{e}}=\left(\left(\gamma_{0}-\gamma_{\mathrm{e}}\right) V\right) / m
$$

$c_{\mathrm{e}}-$ adsorbent phase concentration after equlibrium , $\mathrm{mg} / \mathrm{g}$

$\gamma_{0}$ - initial concentration of adsorbate, $\mathrm{mg} / \mathrm{L}$

$\gamma_{\mathrm{e}}-$ final equlibrium concentration of adsorbate, $\mathrm{mg} / \mathrm{L}$

$V$ - volume of water in reactor, $\mathrm{L}$

$m$ - mass of adsorbent, $\mathrm{g}$ 
Various adsorption isotherms were developed, but the Freundlich isotherm is used more commonly, followed by the Langmuir isotherm.

The Freundlich isotherm is defined as follows (Metcalf \& Eddy, 2003):

$$
c_{\mathrm{e}}=k_{\mathrm{f}} \gamma^{1 / n}
$$

$k_{\mathrm{f}}-$ Freundlichov capacity factor $(\mathrm{mg} / \mathrm{g})(\mathrm{L} / \mathrm{mg})^{1 / \mathrm{n}}$

$1 / n-$ Freundlich intensity parameter,

The constants in Freundlich isotherm can be determined by plotting $\log c_{\mathrm{e}}$ versus $\log \gamma_{\mathrm{e}}$. Eq. 35 can be rewritten as eq. 36 :

$$
\log c_{\mathrm{e}}=\log k_{\mathrm{f}}+1 / \mathrm{n} \log \gamma_{\mathrm{e}}
$$

Langmuir isotherm is defined as (eq. 37):

$$
c_{\mathrm{e}}=\left(a b \gamma_{\mathrm{e}}\right) /\left(1+b \gamma_{\mathrm{e}}\right)
$$

Where

$a$ - empirical constant, $\mathrm{mg} / \mathrm{g}$

$b$ - empirical constant, $\mathrm{cm}^{3} / \mathrm{mg}$

The Langmuir isotherm was developed by assuming that a fixed number of accessible sites are available on the adsorption surface and that adsorption is reversible. Equilibrium is reached when the rate of adsorption of molecules onto activated carbon is the same as the rate of the molecules desorption. The Langmuir isotherm can be rearanged to eq. 38 :

$$
\gamma_{\mathrm{e}} / \mathrm{c}_{\mathrm{e}}=1 /(a b)+\gamma_{\mathrm{e}} / a
$$

\subsection{Pesticide removal achievements by adsorption}

Different adsorption media could be used for atrazine removal such as activated carbon, zeolite, resins, and others (Nyex 100).

Adsorption resins are similar to ion-exchange resins. They express high porosity, include different exchange groups or none, and are utilised for anionic and weak ionic compounds adsorption. Resins could be divided into three groups regarding polarity:

- $\quad$ ion adsorption resins which are strongly base, as used for organic adsorption

- phenole adsorption resins which are weak base amino and phenole groups, used for coloured articles' removal in the food industry;

- inert adsorption resins macroporous copolimers of styrene and divinylbenzene with a high net-degree and high ratio between area and volume; used for weak ionised substances.

Atrazine, simazine and propazine as well as deethylatrazine, deisopropylatrazine and deethyldeisopropylatrazine were efficiently removed when using Calgon WPH and Norit HDB activated carbons. Freundlich constants were calculated, as presented in Table 2, for atrazine and metabolites. Calgon WPH was more efficinet for atrazine removal (Jiang \& Adams, 2006).

Non of the metabolites are formed if atrazine is adsorbed onto activated carbon. The procedure is simple, also for deethylatrazine and in deisopropylatrazine removal. The water solubilty of atrazine is $33 \mathrm{mg} / \mathrm{L}$, for Deethylatrazine and deisopropylatrazine it is higher at $380 \mathrm{mg} / \mathrm{L}$ and $210 \mathrm{mg} / \mathrm{L}$ at $25^{\circ} \mathrm{C}$, respectively. deethylatrazine and deisopropylatrazine expose a lower capacity for activated carbon compared with atrazine, due to the rule 


\begin{tabular}{|c|c|c|c|}
\hline Pesticide & Sample & $k_{\mathrm{f}} /\left((\mathrm{mg} / \mathrm{g})(\mathrm{L} / \mathrm{mg})^{1 / n}\right.$ & $1 / n$ \\
\hline Atrazine & \multirow{3}{*}{ millipore } & $13,518^{\mathrm{a}} 6,15^{\mathrm{b}}$ & $0,491^{\mathrm{a}} 0,4^{\mathrm{b}}$ \\
Deethylatrazine & $1,793^{\mathrm{a}} 5,09^{\mathrm{b}}$ & $0,294^{\mathrm{a}} 0,56^{\mathrm{b}}$ \\
Deisopropylatrazine & & $1,829^{\mathrm{a}} 6,13^{\mathrm{b}}$ & $0,308^{\mathrm{a}} 0,65^{\mathrm{b}}$ \\
\hline Atrazine & \multirow{3}{*}{ groundwater } & $2,211^{\mathrm{a}}$ & $0,358^{\mathrm{a}}$ \\
Deethylatrazine & $0,651^{\mathrm{a}}$ & $0,832^{\mathrm{a}}$ \\
Deisopropylatrazine & & $1,385^{\mathrm{a}}$ & $0,621^{\mathrm{a}}$ \\
\hline Atrazine & \multirow{3}{*}{ millipore } & $10,654^{\mathrm{c}}$ & $0,221^{\mathrm{c}}$ \\
Deethylatrazine & & $1,659^{\mathrm{c}}$ & $0,219^{\mathrm{c}}$ \\
Deisopropylatrazine & & $1,837^{\mathrm{c}}$ & $0,377^{\mathrm{c}}$ \\
\hline Atrazine & \multirow{3}{*}{ groundwater } & $0,885^{\mathrm{c}}$ & $0,973^{\mathrm{c}}$ \\
Deethylatrazine & $0,000^{\mathrm{c}}$ & $7,516^{\mathrm{c}}$ \\
Deisopropylatrazine & & $1,076^{\mathrm{c}}$ & $0,420^{\mathrm{c}}$ \\
\hline
\end{tabular}

Table 2. Freundlih constants for different carbon types ( ${ }^{\mathrm{a} C a l g o n} \mathrm{WPH}$, $\mathrm{Norit} \mathrm{HDB}, \mathrm{pH}=7$, room temperature (Jiang \& Adams, 2006), bCalgon WPL, $\mathrm{pH}=6, \vartheta=21^{\circ} \mathrm{C}$ (Adams \& Watson, 1996))

that substances with higher solubility have lower adsorption capability when binding to activated carbon. Due to this rule, it can be expected that the adsorption capacities of other $\mathrm{s}$-triazine metabolites are lower due to their high solubilities in water. Higher adsoprtion capacities were determined at lower $\mathrm{pH}=6$ compared with higher $\mathrm{pH}$ values (e.g.pH $=8$ ). $\mathrm{pH}$ change within the neutral region does not affect the solubility of atrazine due to $\mathrm{p} K_{\mathrm{a}}$ of atrazine $=1,7$. Adsorption is a reliable treatment method for pollutant removal until certain value. The costs rise very quickly if it is necessary to remove the pollutant below this mentioned value (Adams \& Watson, 1996).

Picabiol and WCM 106 activated carbon gave beter results concerning atrazine removal compared with WCM 106, due to a higher specific area. The efficiency was improved by combinig atrazine adsorption with pre-ozonation (Pryor, 1999). NOM has a huge influence on atrazine adsorption. It was discovered out that 3,4-0,4 $\mathrm{mg} / \mathrm{g}$ lower adsorption capacity within 62 days is achieved due to the high NOM content in water. High DOC also inteferes with atrazine adsorption on granular activated carbon. Up to two thirds lower adsorption capacities were determined (Lebeau et al., 1999).

Organic zeolites were found to exhibit an adsortion capacity for organic pollutants. Clay with negative charge and zeolites have an affinity to cationic exchange. In contrast to clay, zeolites with grain sizes around 1 milimetre or more might be used as filter media for inorganic substances' removal, such as ammonia and heavy metals. If the functional groups on a zeolite surface are replaced by high-molecular weight quarter amine, they could be applied for neionic organic contaminants' removal from water. The capacities for atrazine bonding to stearyle-dimethylbenzi ammonium chloride modified zeolite surfaces was 0,43 $\mathrm{mg} / \mathrm{g}$, following the Langmuir model (Lemić et al., 2006) .

In study in which activated caron, carbonaceous resin and high- silica zeolites were studied to evaluate their effectivenes activated carbon was the most effective and zeolites were less effective because zeolites contain pores of uniform size and shape, and pesticides must matching pore size/shape requirements (Rossner et al., 2009).

Nyex 100 is an adsorption media containing non-porous particles of carbon, and expresses high conductivity. Adsorption and electrochemical regeneration are rapid due to hindered 
intramolecular diffusion. Nyex 100 is a cost-effective carbon dust material with particle diameters from 10 to $600 \mu \mathrm{m}$, and an average diameter of $124 \mu \mathrm{m}$. Its specific area is low at $2,75 \mathrm{~m}^{2} / \mathrm{g}$ whilest activated carbon has $2000 \mathrm{~m}^{2} / \mathrm{g}$. The Freundlich adsorption isotherm for atrazine was calculated at $0,279(\mathrm{mg} / \mathrm{g})(\mathrm{L} / \mathrm{mg})^{1 / n}$, and $1 / n=0,550$ at $\mathrm{pH}=3$, at room temperature $17-26{ }^{\circ} \mathrm{C}$. This is lower compared with activated carbon. If Nyex 100 is electrochemically regenerated using cathode and anode, and salt. However, the adsorption isotherm was similar to when using fresh Nyex 100 (Brown et al., 2004).

Adsorption isotherms were determined using Filtrasorb 400 (Chemviron Carbon) and two resins: Dowex Optipore L 493 (Dow Chemical Company) and Lewatit VP OC 1064 MD PH. The Freundlich equation was employed. Lewatit VP OC 1064 MD PH was the best adsorbent for atrazine, followed by Filtrasorb 400, and Dowex Optipore L 493 resin with only half the Lewatit VP OC 1064 MD PH capacity. Filtrasorb 400 was determined to be the better solution for deethylatrazine removal with a third higher adsorption capacity than Dowex Optipore L 493 (Tepuš et al., 2009).

\section{Membrane technologies}

Over recent years, membranes have become fully or partially integrated into all facilities that produce drinking water (Duranceau, 2000). This is due to the fact that membrane processes can resolve technically complex and, at times, conflicting requirements relating to compliance with multi-contaminant regulations (Taylor \& Hong, 2000). With the tightening of regulations in the future, the need for membrane technology such as reverse osmosis (RO) and nanofiltration (NF) will increase significantly. However, wider use of reverse osmosis membrane technology in the drinking water industry has been hampered greatly by membrane fouling (Hong \& Elimelech, 1997). The extent and rate of membrane fouling are largely affected by membrane surface characteristics (Elimelech et al., 1997; Vrijenhoek \& Hong, 2001).

Because it is generally accepted that, besides the operation values (flux, pressure), membrane performance in $\mathrm{RO}$ and/or NF processes is influenced by membrane porosity and by physicochemical interaction in a system's membrane-water-solute(s) (Kosutic \& Kunst, 2002). It has been discovered, that rejection of the model solution by very tight RO membranes is dominantly affected by the membrane porosity parameters (pore size distribution and effective number of pores), whilst, the rejection of charge ions and organics by NF membrane is expected to be influenced more by the physicochemical parameters (charge, hydrophobicity).

Therefore, in NF retention properties are very important: the possibility of retaining relatively small organic molecules and multivalent ions from aqueous solution is crucial for most applications. NF and RO offer very good removal possibilities for most organic micropollutants, since the molecular weights of these pollutants are often around 200-300 g/ mol, and the molecular weight cut-off (MWCO) values of NF membranes are also often within this region (for RO membranes, the MWCO values are even lower). However, removal of some organic micropollutants is still incomplete and traces may still be detected in the permeate of NF and RO installations (Bellona et al., 2004).

Considering that the molecular weights of almost all pesticides range from 200 to $400 \mathrm{Da}$, NF membranes are potentially useful for pesticide removal. Since NF membranes can simultaneously remove both hardness and pesticides, their application to the treatment of drinking water has been increased (Reinhard et al., 1986; Baier et al., 1987; Duranceau et al., 1992; Hofman et al., 1993; Berg et al., 1997; Hofman et al., 1997; Van der Bruggen et al., 1998). 


\section{General}

Membrane separation is addressed as a pressure-driven process. Pressure driven processes are commonly divided into four overlapping categories of increasing selectivity: microfiltration (MF), ultrafiltration (UF), nanofiltration (NF), and hyperfiltration or reverse osmosis (RO). MF can be used to remove bacteria and suspended solids with pore sizes of 0.1 to micron. UF will remove colloids, viruses and certain proteins with pore sizes of 0.0003 to 0.1 microns. NF relies on physical rejection based on molecular size and charge. Pore sizes are within the range 0.001 to 0.003 microns. $\mathrm{RO}$ has a pore size of about 0.0005 microns and can be used for desalination (Mulder, 1991).

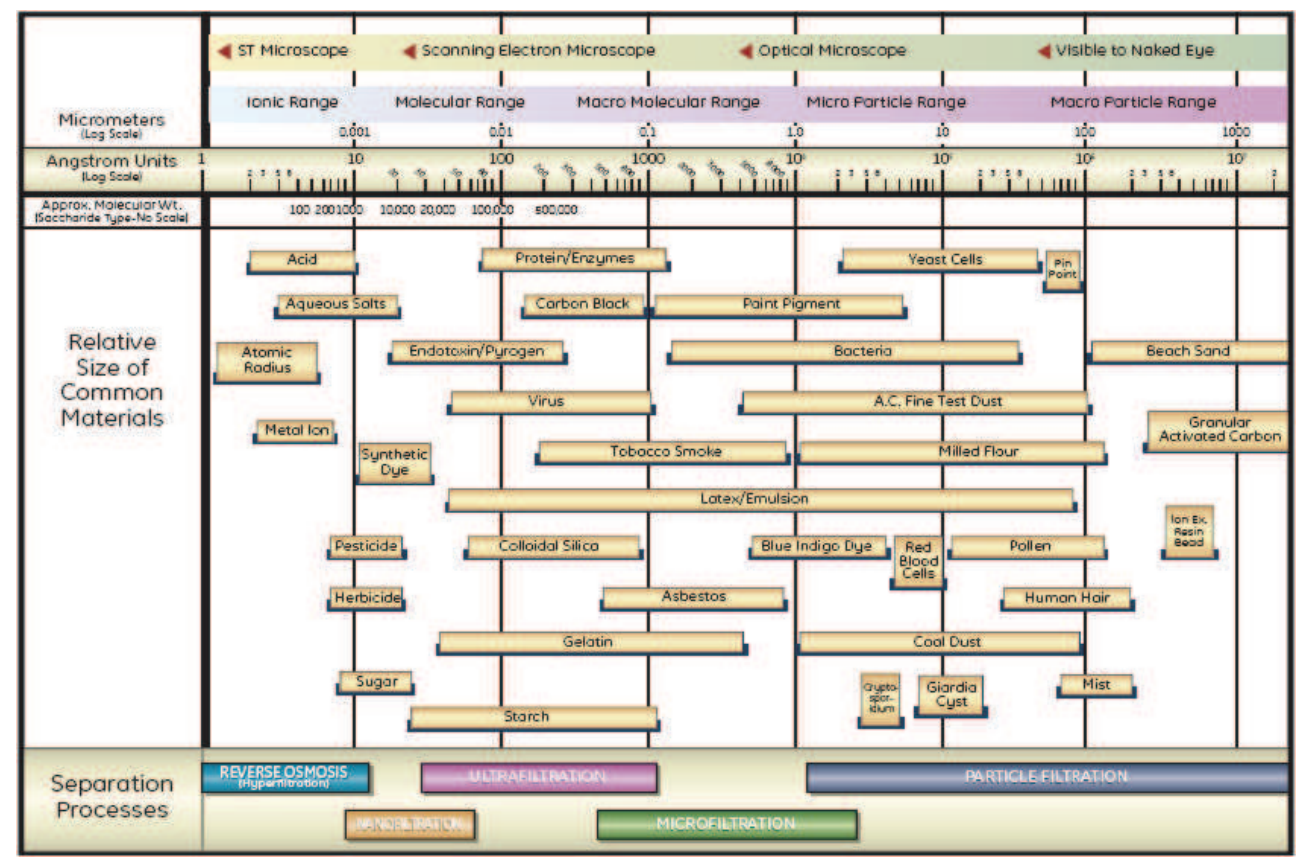

Fig. 1. Filtration and Separation Spectrum (Aim Filtration Systems, Aug. 2010).

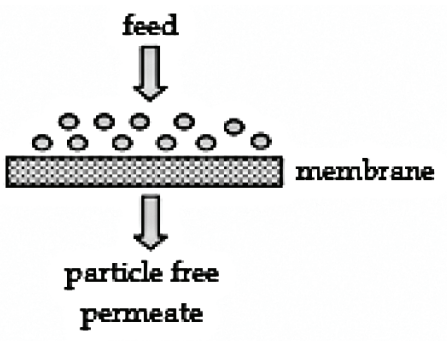

a)

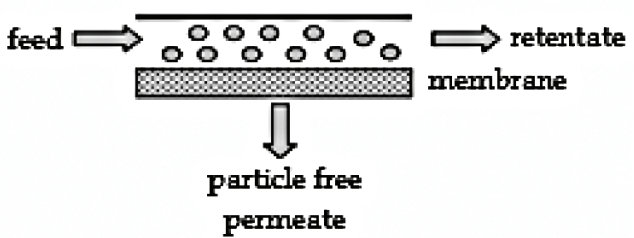

b)

Fig. 2. Comparison between: (a) dead-end, (b) cross-flow configuration (Saxena et al., 2009). 
During membrane filtration, there are two major filtration modes, dead-end filtration and cross-flow filtration. In the cross-flow mode, the fluid to be filtered flows parallel to the membrane surface and permeates through the membrane due to pressure difference. The cross-flow reduces the formation of the filter cake to keep it at a low level (Negaresh, 2007).

\section{Membrane Materials}

The membrane material refers to the substance from which the membrane itself is made. Normally, the membrane material is manufactured from a synthetic polymer, although other forms, including ceramic and metallic "membranes," may be available (Allgeier, 2005). MF and UF membranes may be constructed from a wide variety of materials, including cellulose acetate (CA), polyvinylidene fluoride (PVDF), polyacrylonitrile (PAN), polypropylene (PP), polysulfone (PS), polyethersulfone (PES), or other polymers. Each of these materials has different properties with respect to surface charge, degree of hydrophobicity, $\mathrm{pH}$ and oxidant tolerance, strength, and flexibility.

$\mathrm{NF}$ and RO membranes are generally manufactured from cellulose acetate or polyamide materials (and their respective derivatives), and there are various advantages and disadvantages associated with each. While cellulose membranes are susceptible to biodegradation and must be operated within a relatively narrow $\mathrm{pH}$ range of about 4 to 8 , they do have some resistance to continuous low-level oxidant exposure. Polyamide (PA) membranes, by contrast, can be used under a wide-range of $\mathrm{pH}$ conditions and are not subject to biodegradation. Although PA membranes have very limited tolerance for the presence of strong oxidants, they are compatible with weaker oxidants such as chloramines. PA membranes require significantly less pressure to operate and have become the predominant material used for NF and RO applications (Allgeier, 2005).

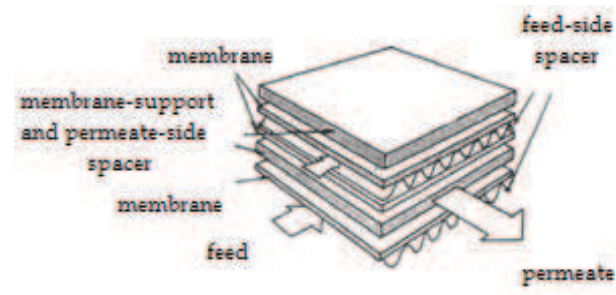

a)

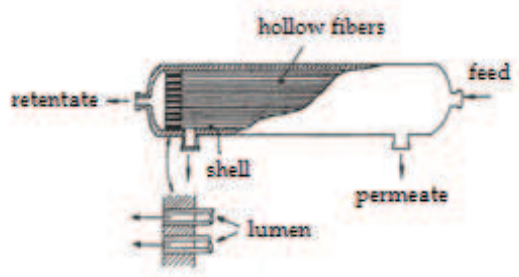

c)

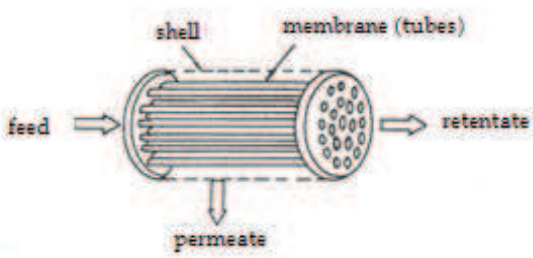

b)

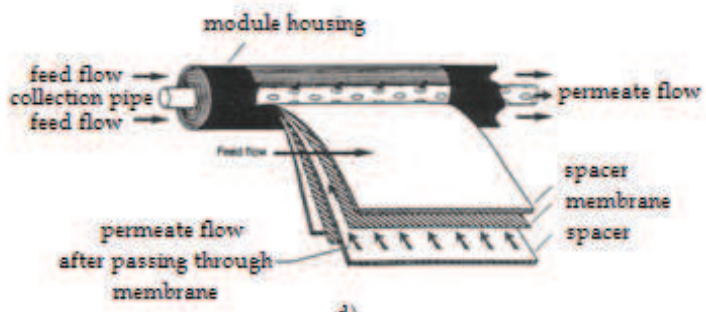

d)

Fig. 3. Membrane module: a) Plate-and-frame membrane module b) Tubular membrane module c) Hollow fibre module with opened-end design d) Spiral Wound Membrane Module (Mulder, 1991). 


\begin{tabular}{|c|c|c|c|c|}
\hline & $\begin{array}{l}\text { Reverse } \\
\text { Osmosis }\end{array}$ & Nanofiltration & Ultrafiltration & Microfiltration \\
\hline Membrane & Asymmetrical & Asymmetrical & Asymmetrical & $\begin{array}{l}\text { Symmetrical } \\
\text { Asymmetrical }\end{array}$ \\
\hline $\begin{array}{l}\text { Thickness } \\
\text { Thin film }\end{array}$ & $\begin{array}{l}150 \mu \mathrm{m} \\
1 \mu \mathrm{m}\end{array}$ & $\begin{array}{l}150 \mu \mathrm{m} \\
1 \mu \mathrm{m}\end{array}$ & $\begin{array}{l}150-250 \mu \mathrm{m} \\
1 \mu \mathrm{m}\end{array}$ & $10-150 \mu \mathrm{m}$ \\
\hline Pore size & $<0.002 \mu \mathrm{m}$ & $<0.002 \mu \mathrm{m}$ & $0.2-0.02 \mu \mathrm{m}$ & $4-0.02 \mu \mathrm{m}$ \\
\hline $\begin{array}{l}\text { Rejection } \\
\text { of }\end{array}$ & $\begin{array}{l}\text { HMW, } \\
\text { LMWC, } \\
\text { sodium } \\
\text { chloride, } \\
\text { glucose, } \\
\text { amino acids }\end{array}$ & $\begin{array}{l}\text { HMWC } \\
\text { mono-,di- and } \\
\text { oligosaccharides, } \\
\text { polyvalent neg. } \\
\text { ions }\end{array}$ & $\begin{array}{l}\text { Macro } \\
\text { molecules, } \\
\text { Proteins, } \\
\text { Polysaccharides, } \\
\text { vira }\end{array}$ & $\begin{array}{l}\text { Particles, } \\
\text { Clay, } \\
\text { Bacteria }\end{array}$ \\
\hline $\begin{array}{l}\text { Membrane } \\
\text { material(s) }\end{array}$ & $\begin{array}{l}\text { CA } \\
\text { Thin film }\end{array}$ & $\begin{array}{l}\text { CA } \\
\text { Thin film }\end{array}$ & $\begin{array}{l}\text { Ceramic, } \\
\text { PSO, PVDF, CA } \\
\text { Thin film }\end{array}$ & $\begin{array}{l}\text { Ceramic, } \\
\text { PP, PSO, PVDF }\end{array}$ \\
\hline $\begin{array}{l}\text { Membrane } \\
\text { Module }\end{array}$ & $\begin{array}{l}\text { Tubular, } \\
\text { Spiral wound, } \\
\text { Plate-and- } \\
\text { frame }\end{array}$ & $\begin{array}{l}\text { Tubular, } \\
\text { Spiral wound, } \\
\text { Plate-and-frame }\end{array}$ & $\begin{array}{l}\text { Tubular, } \\
\text { Hollow fiber, } \\
\text { Spiral wound, } \\
\text { Plate-and-frame }\end{array}$ & $\begin{array}{l}\text { Tubular, } \\
\text { Hollow fiber }\end{array}$ \\
\hline $\begin{array}{l}\text { Operating } \\
\text { pressure }\end{array}$ & 15-150 bar & 5-35 bar & $1-10$ bar & $<2$ bar \\
\hline
\end{tabular}

Table 3. Comparing four membrane processes (Wagner, 2001).

\section{Membrane Modules}

The feasibility of a membrane process depends on the design of membrane module since the active separation membrane area is directly influenced by the membrane modules configuration. Plate-and-frame and tubular membrane module are two of the earliest module designs based on simple filtration technology. Both systems are still available today but, due to their relatively high cost and inefficiency, they have been mainly substituted by hollow fiber and spiral wound membranes (Cheryan, 1998).

\section{Nanofiltration principle and mechanism}

Among all the separation operations in the liquid phase using membranes, nanofiltration (NF) is the latest one to be developed. NF is a process located between UF and RO. Some authors refer to NF as charged UF (Simpson et al., 1987), softening, low pressure RO (Rohe et al., 1990). NF is generally expected to remove 60 to $80 \%$ of hardness, $>90 \%$ of colour, and all turbidity. The process has the advantage of low operating pressures compared to $\mathrm{RO}$, and a high rejection of organics compared to UF. Monovalent salt is not retained to a significant extent; however this is not normally required in the water treatment of surface water.

\section{Rejection Mechanisms}

Due to its small pore size, the observed mass transfer mechanism for NF is diffusion and convection. In addition, the active normal layer normally consists of negatively-charged 
chemical groups, thus mass transfer via migration of ions in an electrical field must also be considered (Tsuru T. et al., 1991). The transport mechanism is normally explained in terms of charge and or size effects (Peeters J. M. M, 1999). Transport of uncharged solutes takes place by convection due to a pressure difference and by diffusion due to the concentration gradient across the membrane. A sieving mechanism is responsible for the retention of the uncharged solutes. For charged components an electrostatic interaction takes place between the component and the membrane as the most nanofiltration membrane is charged (mostly negatively). The effect of membrane charge on the transport of charged components has already been described by Donnan at the beginning of the $20^{\text {th }}$ century.

\section{Equilibrium/Fixed charge effects}

For charged solutes two additional mechanisms can be recognised:

\section{Donnan exclusion:}

When a charged membrane is placed in a salt solution, equilibrium occurs between the membrane and the solution. Because of the presence of the fixed membrane charge, the ionic concentration in the membrane is not equal to those in a solution. The counter-ion (opposite sign of the charge to the fixed charge in the membrane) concentration is higher in the membrane phase than in the bulk solution, while the co-ions (same sign of charge at the fixed membrane charge) concentration is lower in the membrane phase. A potential difference at the inter-phase, called the Donnan potential, is created to counteract the transport of counter ions to the solution phase and the co-ions in the membrane phase. When a pressure gradient across the membrane is applied, water is transported though the membrane. The effect of the Donnan potential is then to repeal the co-ions from the membrane. Because of the electro-neutrality requirements the counter ion is also rejected and salt retention occurs.

For every charge that passes through the membrane, an opposite charge must also pass to maintain charge-neutrality. This phenomenon is complicated since different ions have different diffusivities. So alone each ion would move through the membrane at a different speed. When several different ions are passing through the membrane together some are slowed down and some are sped up in order to maintain charge neutrality.

\section{Dielectric exclusion:}

Dielectric exclusion, which does not generally play a role in ultrafiltration and microfiltration but is of major importance in electrodialysis (Bontha \& Pintauro, 1994). Due to the charge of the membrane and the dipole momentum of water, water molecules will show a polarisation in the pore. This polarisation results in a decrease in the dielectric constant inside the pore, thereby making it less favourable for a charged-solute to enter. However, even in a situation that the dielectric constant inside the pore is equal to the one of water, a change in electrostatic free-energy of the ion occurs when the ion is transferred from the bulk into the pore. This also results in exclusion. The relative importance of two mechanisms in NF is still a point of debate within the scientific community (Hagmeyer \& Gimbel, 1998, Yaroshchuk, 2000). Most of literature on NF uses Donnan exclusion as the distribution mechanism (Tsuru et al., 1991, Wang et al., 1995, Bowen \& Mukhtar, 1996).

The principal transport mechanisms of NF are depicted in Figure 4.

Macoun (Macoun, 1998) summarised NF rejection mechanisms as follows: 
- Wetted Surface - water associates with the membrane through hydrogen bonding and those molecules which form hydrogen bonds with the membrane can be transported,

- Preferential Sorption/Capillary Rejection - the membrane is heterogeneous and microporous, electrostatic repulsion is based on different electrostatic constants in solution and membrane,

- Solution Diffusion - membrane is homogeneous and non-porous, solute and solvent dissolve in the active layer and diffusion determines transport,

- Charged Capillary - the electric double layer in pores determines rejection, ions of same charge as membrane are attracted and counter-ions are rejected due to the streaming potential,

- Finely Porous - membrane is a dense material punctured by pores, transport is determined by partitioning between bulk and pore fluid.

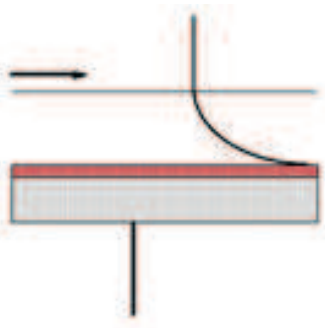

a)
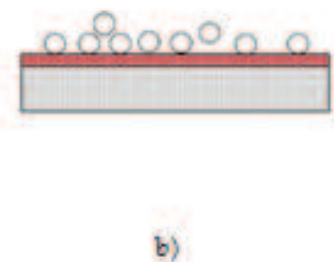

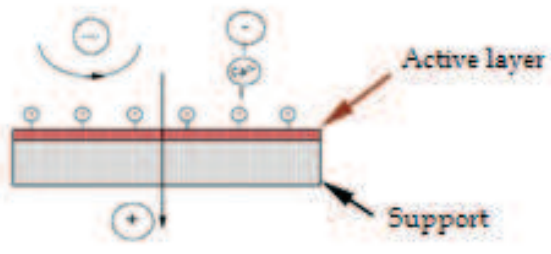

c)

Fig.4. Transport phenomena in NF, (a) concentration polarisation (b) sieving (c) charge effects (e.g. charge repulsion or electrical double layer formation).

\section{Filtration Models}

The Extended-Nernst Planck Equation (equation (39)) is a means of describing NF behaviour. The extended Nernst Planck equation, proposed by Deen (Deen et al., 1980), includes the Donnan expression, which describes the partitioning of solutes between solution and membrane. The model can be used to calculate an effective pore size (which does not necessarily mean that pores exist), and to determine thickness and effective charge of the membrane. This information can then be used to predict the separation of mixtures (Bowen \& Mukhtar, 1996). No assumptions regarding membrane morphology are required (Peeters, 1997). The terms represent transport due to diffusion, electrical field gradient and convection, respectively. $\mathrm{J}_{\mathrm{Si}}$ is the flux of an ion $\mathrm{i}, \mathrm{D}_{\mathrm{I}, \mathrm{P}}$ is the ion diffusivity in the membane, $\mathrm{R}$ the gas constant, $\mathrm{F}$ the Faraday constant, $\Psi$ the electrical potential, and $\mathrm{K}_{\mathrm{I}, \mathrm{c}}$ the convective hindrance factor in the membrane.

$$
J_{s i}=-D_{i, p} \frac{d c_{i}}{d x}-\frac{z_{i} c_{i} D_{i, p}}{R \cdot T} \cdot F \cdot \frac{d \Psi}{d x}+K_{i, c} c_{i} J
$$

The equation predicts solute rejection as a function of feed concentration, ion charge, convection across the membrane, and solute diffusion (Braghetta, 1995). The model has proven to be successful for modelling the solute transport in simple electrolyte solutions, although its applicability in the presence of organics is questionable. 
Wang et al (Wang et al., 1995b) developed the model further to account for the transport phenomena of organic electrolytes, thus combining electrostatic and steric hindrance effects. The steric hindrance pore model suggested by Nakao et al. (Nakao et al., 1982) was incorporated into the modified Nernst Planck equation. For mixed solutions, hindered diffusivity becomes more significant. The rejection depends on electrolyte concentration and the membrane charge increases with salt concentration. This indicates co-ion adsorption on the membrane and, in fact, the effective membrane charge was described as a Freundlich isotherm being function of bulk concentration by Bowen and Mukhtar (Bowen \& Mukhtar, 1996).

The Fine Porous Model, as presented by Xu and Spencer (Xu \& Spencer, 1997), describes the equilibrium and non-equilibrium factors of rejection. Only coupling between solvent and solute is taken into account, and no solute-solute coupling is permitted. Equilibrium parameters dominated separation, and these are described by the reflection coefficient $\sigma$ in equation (40), where $\mathrm{k}_{\mathrm{M}}$ is the solute mass transfer coefficient in the membrane.

$$
R=1-\left[1+\left(\frac{\sigma}{1-\sigma}\right) \cdot\left(1-e^{-\frac{J}{k_{M}}}\right) \cdot e^{-\frac{J}{k_{S}}}\right]^{-1}
$$

The Hindrance Pore Model was introduced by Wang et al. (Wang et al, 1995). This model also allows the calculation of an effective pore radius and the ratio of membrane porosity to membrane thickness. As can be seen with the various models, determination of an effective pore size has become an issue. This is due to the fact that NF pores are too small to be measured directly by various methods, as in MF or UF.

\section{Micropollutants removal using NF}

Viable technologies to remove micropollutants, such as pesticides and alkyl phthalates and NOM from water of impaired quality are high-pressure membrane processes such as nanofiltration (NF) or reverse osmosis (RO). In past research, it has been demonstrated that some micropollutants such as pesticides (e.g., atrazine) can be effective by NF membranes (Kiso et al., 2001; Kiso et al., 2000; Cho et al., 1999; Kiso et al., 2001; Kiso et al., 2002).

Pesticide rejection by NF and RO membranes is thought to be influenced by compound physical-chemical properties (e.g., molecular size, solubility, diffusivity, polarity, hydrophobicity, and charge), membrane properties (e.g., permeability, pore size, hydrophobicity, and charge), and membrane operating conditions (e.g., flux, transmembrane pressure, and recovery). Several studies have reported that the molecular size of the molecule was the most important structural property for retention (Van der Bruggen et al., 1999; Ozaki \& Li, 2002). In addition to steric hindrance, Kiso et al. (Kiso et al. 2000; Kiso et al. 2001; Kiso et al. 2001) determined the hydrophobicity of compounds quantified as n-octanol/water partition coefficient (Kow), as another key parameter for rejection. Studies conducted by Van der Bruggen et al. (Van der Bruggen et al., 1998) using NF membranes indicated that a higher dipole moment resulted in a lower retention and that the retention of a compound with a high dipole moment was lower than that expected when based on molecular size. Most of these studies used surrogate compounds (e.g., alcohols) or pesticides; in many cases, higher than relevant concentrations were employed. There is still a lack of understanding about whether DBPs/EDCs/PhACs (disinfection byproducts/endocrine disruptors/Pharmaceuticals) can be sufficiently removed by NF and RO membranes. (Kimura et al., 2003) 
Studies above pesticide removal have mostly focused on the removal mechanisms between pesticides and membranes. Van der Bruggen et al. (Van der Bruggen et al., 1998; Van der Bruggen et al., 1999) demonstrated that molecular weight and size were the most critical mechanisms for pesticide removal using different kinds of NF membranes. Kiso et al. (Kiso et al., 2000; Kiso et al., 2001; Kiso et al., 2001; Kiso et al., 2002) studied the rejection of alkyl phthalates, nonphenylic pesticides, and aromatic pesticides by flat-sheet and hollow fine fibre types membranes. Both RO and NF were used in their studies. The results also showed that molecular weight, size, and hydrophobicity were all significant. However, the combined effect of the flux, recovery, molecular weight and size were seldom discussed together, although flux and recovery are two of the critical operational parameters for NF membranes.

A single-element Filmtec NF70 nanofilter was operated for six 1-month periods in which each of the pesticides was studied (Duranceau et al., 1992). The results showed that rejection of these six pesticides was dependent on pesticide molecular weight. EDB (molecular weight 190) completely passed the NF70 for all test conditions. DBCP (molecular weight 236) was partially rejected and indicated diffusion control mass transport. All other pesticides having molecular weights greater than 278 were completely rejected by the membrane. Variations in recovery and feed-stream velocity had no effect on pesticide rejection by the membrane with the exception of Dibromochloropropane, which did show an increase in permeate concentration $\mathrm{w}$ ith increasing recovery.

The removal of simazine, atrazine, diuron, bentazone, DNOC, and dinoseb has also been investigated using four different nanolilters - Fluid Systems 4 21PZ, Filmtec NF70, Hydranautics PVD 1, and a Toray SU6 10 on a pilot scale in the Netherlands by KIWA (Hofman et al., 1993). Atrazine was as consistently rejected as any pesticide, which was due to steric effects; diuron was the most poorly-rejected pesticide. These results showed that pesticide rejection varied by membrane and did not always increase with pesticide molecular weight. Lower rejection of diuron with the NF70 membrane might have been due to the surface interaction of the membrane film with the diuron.

Another pilot plant was operated in Germany for a 5-month period, in order to study the rejection of simazine, atrazine, diuron, terbutylazine by a Hydranautics PVD- 1, polyvinyl alcohol membrane. For $75 \%$ recovery, simazine, atrazine, terbutylazine were rejected over $90 \%$ and diuron was rejected for about $85 \%$. Diuron was again the lowest rejected pesticide in this study. When the recovery increased to $80 \%$, all the pesticide rejection was decreased by about $5 \%$. This result can be explained by the higher concentration in the feed-side, which results in high permeate concentration in the diffusion-controlled membrane system. The rejection properties of pesticides and alkyl phthalates were examined using flat-sheettype NF membranes (Kiso et al., 2000; Kiso et al., 2000; Kiso et al., 2001) and the following results obtained: (1) higher desalting NF membranes rejected almost all solutes at more than $95 \%$, (2) some compounds were rejected effectively even by lower desalting membranes, (3) the rejection properties were influenced, not only by steric hindrance, but also by an affinity to the membrane. The rejection properties of a hollow-fiber membrane (HNF- 1) for nonphenilic pesticides were also investigated in our previous work (Kiso et al., 2002) where the rejection properties were discussed on the basis of short-term $(5 \mathrm{~h})$ of membrane separation experiments. The fact that the pesticides were adsorbed on the membrane suggested that it is necessary to conduct the experiments for longer periods, in order to evaluate the effects of the adsorption. In addition, it was found that aromatic pesticides were adsorbed more than non-aromatic pesticides. (Yung et al., 2005) 
Van der Bruggen et al. (Van der Bruggen et al., 2006) attempted to develop a semiquantitative method for estimating rejection of organic micropollutants by NF. This model provides an approximation of rejection by taking into account compound molecular weight, hydrophobicity, and charge combined with the membrane's molecular weight cut-off (MWCO) and surface charge. Further development of this type of model is needed as molecular parameters including, among others, dipole moment and effective hydrated radius, along with membrane parameters such as pore size distribution, hydrophobicity and charge are not excluded. It is also important that operational parameters are considered, such as recovery and cross-flow velocity.

In addition, an increase in compound rejection may result from the binding of EDCs and PhACs to NOM due to hydrogen bonding, forming NOM-compound complexes that are larger, have an increased negative-charge, and/or a higher affinity for adsorption to the membrane when compared to the compound alone (Plakas et al., 2006; Zhang et al., 2004; Devitt et al., 1998). The presence of cations can also influence the membrane charge and the interaction of compounds and humic acids with each other and the membrane surface (Cho et al., 2000; Jucker \& Clark, 1994). For example, Devitt et al. (Devitt et al., 1998) investigated the rejection of atrazine by NF and UF membranes and observed that atrazine-NOM association decreased in the presence of cations (principally calcium). Plakas et al. (Plakas et al., 2006) studied the removal of atrazine, isoproturon and prometryn by NF and found that the presence of calcium ions alone has a positive effect on pesticide retention but can interfere with the pesticide-NOM complex, thus reducing overall retention. (Comerton et al., 2008)

\section{Conclusion}

Atrazine is still one of the most commonly used herbicides in the world and is used on most corn, sugarcane and sorghum acreage in the United States. It is used to stop pre- and postemergence broadleaf and grassy weeds, and is generally applied in the spring. Thus, atrazine concentrations are greatest in streams during the spring, when most fish in North America are attempting to reproduce. Investigations and evaluations of the potential risks posed by atrazine, particularly in wild populations of fish from streams in agricultural areas with high use of this herbicide are still the important issue worldwide.

\section{References}

Acero J. L., von Gunten (1998). Influence of carbonate on advanced oxidation process for drinking water treatment, Proceedings of ozonation and AOPs in water treatment: Application and research, Poitiers, France, 23-25 Septemebr, 13.1-13.9.

Acero J. L. \& Von Gunten U. (2001). Characterization of oxidation processes: ozonation and the $\mathrm{AOP} \mathrm{O} 3 / \mathrm{H}_{2} \mathrm{O}_{2}$, Journal Awwa, 90-100.

Acero J. L., Stemmler K. \& von Gunten U. (2000). Degradation kinetics of atrazine and its degaradtion products with ozone and $\mathrm{OH}$ radicals: a predictive tool for drinking water treatment, Environ. Sci. Technol., 34, 591-597.

Adams C. D. \& Watson T. L. (1996). Treatability of s-triazine herbicide metabolites using powdered activated carbon, Journal of environmental engineering, 327-330.

AIM Filtration Systems, Filtration and Separation, <http:/ / www.filters-cartridges.com/filtration-spectrum.html>, August 2010. 
Allgeier S. (2005). Membrane Filtration Guidence Manual, Edited by Malcolm Pirnie, Inc., Separation Processes, Inc., and The Cadmus Group, Inc., US EPA's Office of Water.

Andreozzi R., Caprio V., Insola A., Marotta R. (1999). Advanced oxidation processes (AOP) for water purification and recovery, Catalysis Today, 53, 51-59.

Arnold S. M., Hickey W. J. \& Harris R. F. (1995). Degradation of atrazine by Fenton s reagent: condition optimization and product quantification, Environ. Sci. Technol., 29, 2083-2089.

Baier J.H., Lyskins Jr. B.W., Fronk C.A., Kramer S.J. (1987). Using reverse osmosis to remove agricultural chemicals from ground water. Journal American Water works Association, $79,55$.

Balci B., Oturan N., Cherrier R., Oturan M. A. (2009). Degradation of atrazine in aqueous medium by electrocatalytical generated hydroxyl radicals. A kinetic and mechanistic study, Wat. Res., 43, 1924-1934.

Barreiro J. C., Capelato M. D., Martin-Neto L., Hansen H. C. B. (2007). Oxidative decomposition of atrazine by a Fenton-like reaction in a $\mathrm{H}_{2} \mathrm{O}_{2}$ / ferrihydride system, War. Res., 41, 55-62.

Bellona C., Drewes J.E., Xu P., Amy G. (2004). Factors affecting the rejection of organic solutes during NF/RO treatment - a literature review. Water Research, 38, 2795.

Beltran F. J. (1996). Theoretical aspects of the kinetics of competitive first reactions of ozone in the $\mathrm{O}_{3} / \mathrm{H}_{2} \mathrm{O}_{2}$ and $\mathrm{O}_{3} / \mathrm{UV}$ oxidation processes, Ozone Science $\mathcal{E}$ Engineering, 13-38.

Beltran F. J., Gonzalez M., Acedo b. \& Rivas F. J. (2000). Kinetic modelling of aqueous atrazine ozonation processes in a continuous flow bubble contactor, Journal of Hazardous Materials, B(80), 189-206.

Berg P., Hagmeyer G., Gimbel R. (1997). Removal of pesticides and other micropollutants by nanofiltration. Desalination, 113, 205-208.

Bolzacchini E., Brambilla A., Orlandi M., Polesello S. \& Rindone B. (1994). Oxidative pathways in the degradation of triazine herbicides: a mehanistic approach, Wat. Sci. Tech., 30(7), 129-136.

Bontha J.R. \& Pintauro P.N. (1994). Water orientation and ion solvation effects during multicomponent salt partitioning in a nafion cation exchange membrane. Chem. Eng. Sci., 49, 3835-3851.

Boussahel R., Bouland S., Moussaoui K.M., Montiel A. (2000). Removal of pesticide residues in water using the nanofiltration process. Desalination, 132, 205-209.

Bowen W.R., Mukhtar H. (1996). Characterisation and prediction of separation performance of nanofiltration membranes. Journal of Membrane Science, 112, 263-274.

Braghetta A. (1995). The influence of solution chemistry and operating conditions on nanofiltration of charged and uncharged organic macromolecules. Dissertation, University of North Carolina, Chapel Hill.

Brown N. W., Roberts E.P.L., Chasiotis A., Cherdron T. \& Sanghrajka N., (2004). Atrazine removal using adsrobption and electrochemical regeneration, Wat. Res., 38, 30673074 .

Chan K. H. \& Chu W. (2003). The system design of atrazine oxidation by catalytic oxidation process through a kinetic approach, Wat. Sci., 37, 3997-4003.

Chan K. H. \& Chu W. (2005). Model application and mechanism study on the degradation of atrazine by Fenton s system, Journal of Hazardous Material, B118, 227-237. 
Chan K. H. \& Chu W. (2009). Degradation of atrazine by cobalt-mediated activation of peroxymonosulfate: Different cobalt conteranions in homogenous process and cobalt oxide catalysts in photolytic heterogenous process, Wat. Res., 43, 2513-2521.

Cheryan M. (1998). Ultrafiltration and microfiltration handbook. University of Illinois, USA. Technomic publishing company, Inc., USA.

Chiron S., Fernandez- Alba A., Rodriguez A. \& Garcia-Calvo E. (2000). Pesticide chemical oxidation: state-of-the-art, Wat. Res., 34 (2), 366-377.

Cho J.W., Amy G., Pellegrino J. (1999). Membrane filtration of natural organic matter: initial comparison of rejection and flux decline characteristics with ultrafiltration and nanofiltration membranes. Water Research, 33, 2517-2526.

Cho J., Amy G., Pellegrino J. (2000). Membrane filtration of natural organic matter: factors and mechanisms affecting rejection and flux decline with charged ultrafiltration (UF) membrane. J. Membr. Sci., 164, 89.

Comerton A.M., Andrewsa R.C., Bagley D.M., Hao C. (2008). The rejection of endocrine disrupting and pharmaceutically active compounds by NF and RO membranes as a function of compound and water matrix properties. Journal of Membrane Science, 313, 323-335.

Deen W.M., Satvat B., Jamieson J.M. (1980). Theoretical model for glomerular filtration of charged solutes. Am. J. Physiol., 238, F126-139.

De Laat J., Chramosta N., Dore M., Suty H. \& Pouillot M. (1994). Constantes Cinétiques de Réaction des Radicaux Hydroxyles sur Quelques Sous-Produits d'Oxydation de l'Atrazine par $\mathrm{O}_{3}$ ou par $\mathrm{O}_{3} / \mathrm{H}_{2} \mathrm{O}_{2}$, Environ. Technology, 15, 419-428.

Devitt E.C., Ducellier F., P. Cote, Wiesner M.R. (1998). Effects of natural organic matter and the raw water matrix on the rejection of atrazine by pressuredriven membranes. Wat. Res., 32 (9), 2563.

Duranceau S. (2000). Future of membranes. Journal American Water works Association, 92, 7071.

Duranceau S.J., Taylor J.S., Mulford L.A. (1992). SOC removal in a membrane softening process. Journal American Water works Association, 84, 68-78.

Elimelech M., Zhu X.H., Childress A.E., Hong S. (1997). Role of surface morphology in colloidal fouling of cellulose acetate and composite polyamide RO membranes. Journal of Membrane Science, 127 (1), 101-109.

Gallard H. \& De Laat J. (2000). Kinetic modelling of $\mathrm{Fe}^{3+} / \mathrm{H}_{2} \mathrm{O}_{2}$ oxidation reactions in dilute aqueous solution using atrazine as a model organic compound, Wat. Res., 34 (12), 3107-3116.

Gonzalez M. C. \& Martire D. O. (1997). Kinetics of $\mathrm{O}^{0-}$ in $\mathrm{O}_{3}{ }^{0-}$ in alkaline aqueous solutions, Wat. Sci. Tech., 35(4), 49-55.

Garmouna M., Blanchard M., Chesterikoff A., Ansart P. \& Chevreuil M. (1997). Sesonal trasnport of herbicides (triazines and phenylureas) in a small stream draining an agricultural basin: Melarchez (France), Wat. Res., 31(6), 1489-1503.

Gottschalk, C., Libra J. A. \& Saupe A. (2000). Ozonation of Water and Waste Water, WileyVHC: Federal Republic of Germany, 11-20, 120-121.).

Haag W. R.\& Yao C. C. D. (1992). Rate constants for reaction of hydroxyl radicals with several drinking water contaminants, Environ. Sci. Technol., 26, 1005-1013. 
Haarhoff J., Kubare M., Mamba B., Krause R., Nkambule T., Matsebula B. \& Menge J. (2010). NOM characterization and removal at six Southern African water treatment plants Drink. Water Eng. Sci., 3, 53-61.

Hagmeyer G. \& Gimbel R. (1999). Modelling the rejection of nanofiltration membranes using zeta potential measurements. Sep. Purif. Technol, 15, 19-30.

Hapeman C. J. (1994). Oxidation of s-triazinepesticides. In Teller, D. W., Pohland, F. G. (Eds.), Emerging Technologies in Hazardous Waste Management IV, ACS Syposium Series, American Chemical Society, 223-233.

Hermanowicz S. W., Bellamy W. D. \& Fung L. C. (1999). Variability of ozone reaction kinetics in batch and continuous flow reactors, Wat. Res., 33 (9), 2130-2138.

Hoigne J. (1997). Inter-calibration of $\mathrm{OH}$ radicals sources and water quality parameter, Wat. Sci. Tech., 35 (4), 1-8.

Hoigne J. (1998). Chemistry of aqueous ozone and transformation of pollutans by ozonation and advanced oxidation processes, Part C, Quality and treatment of drinking water II, The handbook of environmental chemistry, Vol 5, ed. J. Hrubec, Springer- Verlag, Berlin Heidelberg, 83-141.

Hong S.K., Elimelech M. (1997). Chemical and physical aspects of natural organic matter (NOM) fouling of nanofiltration membranes. Journal of Membrane Science, 132, 159181.

Hofman J.A.M., Noij Th.H.M., Schippers J.C. (1993). Removal of pesticides and other organic micropollutants with membrane filtration. Water Supply, 11, 101.

Hofman J.A.M.H., Beerendonk E.F., Folmet H.C., Kruithof J.C. (1997). Removal of pesticides and other micropollutants with cellulose-acetate, polyamide and ultra-low pressure reverse osmosis membranes. Desalination, 113, 209.

Hofman J.A.M.H., Noij Th.H.M., Kruithof J.C., Schippers J.C. (1993). Removal of pesticides by nanofiltration. Proc. AWWA Membrane Technology Conference, Reno, NV.

Huang W. J., Peng M. Y., Chen L. Y. (2004). Removal of bromate and assimilable organic carbon from drinking water using granular activated carbon, Water science and Technology, 50(8), 73-80.

Jiang H. \&Adams C. (2006). Treatability of chloro-s-triazines by conventional drinking water treatment technologies, Wat. Res., 40, 1657-1667.

Jucker C., Clark M.M. (1994). Adsorption of aquatic humic substances on hydrophobic ultrafiltration membranes. J. Membr. Sci., 97, 37.

Jung Y.J., Kiso Y., Othman R.A.A.B., Ikeda A., Nishimura K., Min K.S., Kumano K., Ariji A. (2005). Rejection properties of aromatic pesticides with a hollow-fiber NF membrane. Desalination, 180, 63-71.

Kearney P. C., Muldoon M. T., Somich C. J., Ruth J. M. \& Voaden D. J. (1988). Biodegradation of ozonated atrazine as a wastewater disposal system, J. Agric. Food Chem., 36, 1301-1306.

Kimura K., Amy G., Drewes J., Watanabe Y. (2003). Adsorption of hydrophobic compounds onto NF/RO membranes: an artifact leading to overestimation of rejection. Journal of Membrane Science, 221, 89-101.

Kimura K., Amy G., Drewes J., Heberer T., Kim T., Watanabe Y. (2003). Rejection of organic micropollutants (disinfection by-products, endocrine disrupting compounds, and pharmaceutically active compounds) by NF/RO membranes. Journal of Membrane Science, 227, 113- 121. 
Kimura K., Toshima S., Amy G., Watanabe Y. (2004). Rejection of neutral endocrine disrupting compounds (EDCs) and pharmaceutical active compounds (PhACs) by RO membranes. Journal of Membrane Science, 245, 71-78.

Kiso Y., Nishimura Y., Kitao T., Nishimura K. (2000). Rejection properties of non-phenylic pesticides with nanofiltration membranes. Journal of Membrane Science, 171, 229-237.

Kiso Y., Kon T., Kitao T., Nishimura K. (2001). Rejection properties of alkyl phthalates with nanofiltration membranes. Journal of Membrane Science, 182, 205-214.

Kiso Y., Mizuno A., Othman R., Jung Y.J., Kumano A., Ariji A. (2002). Rejection properties of pesticides with a hollow fiber NF membrane (HNF-1). Desalination, 143, 147-157.

Kiso Y., Sugiura Y., Kitao T., Nishimura K. (2001). Effects of hydrophobicity and molecular size on rejection of aromatic pesticides with nanofiltration membranes. J. Membr. Sci., 192, 1-10.

Kosutic K, Kunst B. Removal of organics from aqueous solutions by commercial RO and NF membranes of characterized porosities. Desalination, 142 (1), 47-56

Lebeau T., Lelievre C., Wolbert D., Laplanche A. (1997). Effect of natural organic matter loading on the atrazine adsorption capacity of an aging powdered activated carbon slurry, Wat. Res., 33(7), 1695-1705.

Legube B., Parinet B., Gelinet K., Berne F. \& Croue J. P. (2004). Modeling of bromate formation by ozonation of surface waters in drinking water treatment, Wat. Res., 38, 2185-2195.

Lemić J., Kovačević D., Tomašević-Čanović Magdalena, Kovačević D., Stanić T. \& Pfend R. (2006). Removal of atrazine, lindane and diazinone from water by organo-zeolites, Wat. Res., 40, 1097-1085.

Ma J. \& N. J. D. Graham, (1997). Preliminary investigation of manganese catalyzed ozonation for the destruction of atrazine, Ozone Science E Engineering, 19, 227- 240.

Ma. J. \& Graham N. J. D. (1999). Degradation of atrazine by manganese- catalysed ozonation: influence of humic substances, Wat. Res., 33 (3), 785-793.

Ma. J. \& Graham N. J. D. (2000). Degradation of atrazine by manganese-catalysed ozonationinfluence of radical scavengers, Wat. Res., 34 (15), 3822-3828.

Macoun R.G. (1998). The mechanisms of ionic rejection in nanofiltration. PhD thesis, UNSW, Chemical Engineering.

Mallevialle J., Odendaal P.E., Wiesner M.R. (1996). Water treatment membrane processes, McGraw-Hill.

Metcalf \& Eddy. (2003). Wastewater engineering treatment and reuse, Fourth edition, McGrawHill Higher education, Chapter 11.

Meunier 1., Canonica S. \& Von Gunten U. (2006). Implication of sequential use of UV and ozone for drinking water quality, Wat. Res., 40, 1864-1876.

Mulder M. (1991). Basic Principles of Membrane Technology, Kluwer Academic Publishers, Dordrecht.

Nakao S., Kimura S. (1982). Models of membrane transport phenomena and their application for ultrafiltration data. J. Chem. Eng. Japan, 15, 200-205.

Negaresh E. (2007). Particle and Macromolecule fouling in Submerged Membrane. Master Thesis, Chemical Sciences \& Engineering, Faculty of Engineering, UNSW.

Nelieu S., Kerhoas L., Einhorn J. (2000). Degradation of atrazine into ammeline by combined ozone/hydrogen peroxide treatment in water, Environ. Sci. Technol., 34, 430-437. 
Nghiem L.D., Schafer A.I., Elimelech M. (2004). Removal of natural hormones by nanofiltration membranes: measurement, modeling, and mechanisms. Environ. Sci. Technol., 38, 1888-1896.

Nghiem L.D., Manis A., Soldenhoff K., Schafer A.I. (2004). Estrogenic hormone removal from wastewater using NF/RO membranes. Journal of Membrane Science, 242, 37-45.

Ni C. H., Chen J. N. \& Yang P. Y. (2002). Catalytic ozonation of 2-dichlorophenol by metallic ions, Water science and Technology, 47, 77- 82.

Official Gazette RS N. 13, (1999). Odločba o prepovedi oziroma omejitvi prometa in uporabe strupenih substanc in iz njih izdelanih preparatov, ki se uporabljajo kot fitofarmacevtska sredstva, Ljubljana, Slovenia.

Ozaki H., Li H. (2002). Rejection of organic compounds by ultra-low pressure reverse osmosis membrane. Wat. Res., 36, 123-130.

Panno S. V.\& Kelly W. R. (2004). Nitrate and herbicide loading in two groundwater basins of Illinois sinkhole plain, Journal of Hydrology, 290, 229-242.

Park J. S., Choi H. \& Cho J. (2004). Kinetic decomposititon of ozone and para-chlorobenzoic acid (pCBA) during catalytic ozonation, Wat. Res., 38, 2285-2292.

Peeters J. M. M. et al. (1999). Streaming potential measurements as a characterization method for nanofiltration membranes. Colloids and Surface: A., 150, 247-259.

Peeters J.M.M. (1997). Characterization of nanofiltration membranes. Dissertation, University of Enschede, Netherlands.

Pelizzeti E., Carlin V., Minero C., Pramauro E. \& Vincenti M. (1992). Degradation pathways of atrazine under solar light and in the presence of $\mathrm{TiO}_{2}$ colloidal particles, The Science of Total Environment, 123/124, 161-169.

Pi Y., Schumacher J. \& Jekel M. (2005). Decomosition of aqueous ozone in the presence of aromatic organic solutes, Wat. Res., 39, 83-88.

Pintar M. \& Lobnik F. (2001). Dinamika pojavljanja pesticidov in nitratov v podtalnici pod intenzionimi kmetijskimi površinami, Proceedings (Zbornik Seminarja): Zdravstvena ustreznost pitne vode in varnost oskrbe, Otočec ob Krki.

Plakas K.V., Karabelas A.J., Wintgens T., Melin T. (2006). A study of selected herbicides retention by nanofiltration membranes - the role of organic fouling. J. Membr. Sci., $284,291$.

Prado J. \& Esplugas S. (1999). Comparison of different advance oxidation processes involving ozona to eliminate atrazine, Ozone Science \& Engineering, 21, 39-52.

Pryor M. J., Nozaic D., Freese S. D. \& Rajagopaul R. (1999). The use of granular activated carbon for the treatment of impounded surface water, Wat. Sci. Tech, 39 (10-11), 197200.

Reid D. C., Dwards A. C., Cooper D., Wilson E. \& Mcgaw B. A. (2003). The quality of drinking water from private water supplies in Aberdeenshire, UK, 37, 245-254.

Reinhard M., Goodman N.L., McCarty P.L., Argo D.G. (1986). Removing trace organics by reverse osmosis using cellulose acetate and polyamide membranes. Journal American Water works Association, 78, 163.

Richards R. P., Baker D. B., Christensen B. R. \& Tierney D. P. (1995). Atrazine exposures through drinking water: Exposure assessments for Ohio, Illinois, and Iowa, Environ. Sci. Technol., 29, 406-412.

Rohe D. L., Blanton T. C., Mariñas B. J. (1990). Drinking Water Treatment by Nanofiltration. National Conference on Environmental Engineering, 707-716. 
Rosenfeldt E. J., Linden K. G., Canonica S., Von Gunten U. (2006). Comparison of the efficiency of $\mathrm{OH}$ radical formation during ozonation and the advanced oxidation processes $\mathrm{O}_{3} / \mathrm{H}_{2} \mathrm{O}_{2}$ and $\mathrm{UV} / \mathrm{H}_{2} \mathrm{O}_{2}$, Wat. Res., 40, 3695-3704.

Rossner A., Snyder S. A., Knappe D. R. U. (2009). Removal of emerging contaminates of concern by alternative adsorbents, Wat. Res., 43, 3787-3796.

Saxena A., Tripathi B.P., Kumar M., Shahi V.K. (2009). Membrane-based techniques for the separation and purification of proteins: An overview. Advances in Colloid and Interface Science, 145, 1-22.

Schafer A. I., Nghiem L. D., Waite T. D. (2003). Removal of the natural hormone estrone from aqueous solutions using nanofiltration and reverse osmosis. Environ. Sci. Technol., 37, 182-188.

Simpson A. E., Kerr C. A., Buckley C. A. (1987). The effect of $\mathrm{pH}$ on the nanofiltration of the carbonate system in solution. Desalination, 64, 305-319.

Sunder M. \& Hempel D. C. (1997). Oxidation of tri- and perchloroethene in aqueous solution with ozone and hydrogen peroxide in a tube reactor, Wat. Res, 31 (1), 33-40.

Taylor J. S., Hong S. K. (2000). Potable water quality and membrane technology. Laboratory medicine, 31, 10, 563-568.

Tepuš B. \& Simonič M. (2007). The effect of platinum catalyst on decomposition of ozone and atrazine removal. Journal of advanced oxidation technologies, 10, 1, 202-208.

Tepuš B. \& Simonič M. (2008). Kinetic Studies of Catalytic ozonation of atrazine, Chroatica Chemica Acta, 81, 4, 673-679.

Tepuš B., Petrinić I., Simonič M. (2009). Comparison between nitrate and pesticide removal from ground water using adsorbents and NF and RO membranes, Journal of Hazardous Materials, 170, 1210-1217.

Thurman E. M., Meyer M. T., Mills M. S., Zimmerman L. R. \& Perry C. A. (1994). Formation and transport of deethylatrazine and deisopropylatrazine in surface water, Environ. Sci. Technol., 28, 2267-2277.

Tsuriu T. et al. (1991). Negative rejection of anions in the loose reverse osmosis separation of mono- and divalent ion mixtures. Desalination, 81, 219-231.

Tsuru T. et al. (1991). Calculation of ion rejection by extended Nernst-Planck equation with charged reverse osmosis membranes for single and mixed electrolyte solutions. J. Chem. Eng. Of Japan, 24, 511-517.

Van der Bruggen B., Schaep J., Maes W., Wilms D., Vandecasteele C. (1998). Nanofiltration as a treatment method for the removal of pesticides from ground waters. Desalination, 117, 139-147.

Van der Bruggen B., Schaep J., Wilms D., Vandecasteele C. (1999). Influence of molecular size, polarity and charge on the retention of organic molecules by nanofiltration. $J$. Membr. Sci., 156, 29-41.

Van der Bruggen B., Verliefde A., Braeken L., Cornelissen E. R., Moons K., Verberk J. Q. J. C., van Dijk H. J. C., Amy G. (2006). Assessment of a semiquantitative method for estimation of the rejection of organic compounds in aqueous solution in nanofiltration. J. Chem. Technol. Biotechnol., 81, 1166.

Verstraeten I. M., Thurman E. M., Lindsey M. E., Lee E. C. \& Smith R. D. (2002). Changes in concentrations of triazine and acetamide herbicides by bank filtration, ozonation and chlorination in public water supply, Journal of hidrology, 26, 190-208. 
Von Gunten U., Ozonation of drinking water: Part I: Oxidation kinetics and product formation, Wat. Res. 37, 2003, 1443-1467.

Vrijenhoek E.M., Hong S., Elimelech M. (2001). Influence of membrane surface properties on initial rate of colloidal fouling of reverse osmosis and nanofiltration membranes. Journal of Membrane Science, 188, 115-128.

Wagner J. (2001). Membrane Filtration Handbook: Practical Tips and Hints, second edition.

Wang, G.-S. \& Alben, K. T. (1988). Effect of preadsorbed background organic matter on granular activated carbon adsorption of atrazin, The science of the Total Environment, $224,221-226$

Wang X.L. et al. (1995). Electrolyte transport through nanofiltration membranes by the space charge model and the comparison with the Teorell Meyer Sievers model. J. Membr. Sci., 103, 117-133.

Wang X.-L., Tsuru T., Togoh M., Nakao S.-i., Kimura S. (1995). Evaluation of pore structure and electrical properties of nanofiltration membranes. Journal of Chemical Engineering of Japan, 28, 2, 186-192.

Wang X.-L., Tsuru T., Togoh M., Nakao S.-i., Kimura S. (1995). Transport of organic electrolytes with electrostatic and steric-hindrance effects through nanofiltration membranes. Journal of Chemical Engineering of Japan, 28, 4, 372-380.

Xu X., Spencer H.G. (1997). Transport of electrolytes through a weak acid nanofiltration membrane: effects of flux and crossflow velocity interpreted using a fine-porous membrane model. Desalination, 113, 85-93.

Yaroshchuk A.E. (2000). Dielectric exclusion of ions from membranes. Adv. Coll. Int. Sci., 85, 193-230.

Yoon Y., Westerhoff P., Yoon J., Snyder S.A. (2004). Removal of 17 bestradiol and fluoranthene by nanofiltration and ultrafiltration. J. Environ. Eng.-ASCE, 130, 14601467.

Zhan Z., Müllner M. \& Lercher J. A. (1996). Catalytic hydrolysis of s-triazine compounds over $\mathrm{Al}_{2} \mathrm{O}_{3}$, Catalysis Today, 27, 167-173.

Zhang Y., Van den Bruggen B., Chen G. X., Braeken L. \& Vandecasteele C. (2004). Removal of pesticides by nanofiltration: effect of the water matrix, Separation and Purification Technology 38, 163-172.

Zhang Y., Ban der Bruggen B., Chen G.X., Braeken L., Vandecasteele C. (2004). Removal of pesticides by nanofiltration: effect of water matrix. Sep. Purif. Technol., 38, 163.

Zhu X., Elimelech M. (1995). Fouling of reverse osmosis membranes by aluminium oxide colloids. Journal of Environmental Engineering, 121, 884-892.

Ziegmann M., Doll T. \& Frimmel F. H. (2006). Matrix effects on the photocatalytical degradation of dichloroacetic acid and atrazine in water, Acta Hydrochim. Hydrobiol., 34, 146-154. 


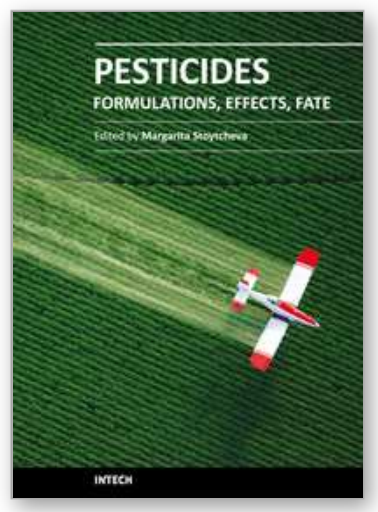

\author{
Pesticides - Formulations, Effects, Fate \\ Edited by Prof. Margarita Stoytcheva
}

ISBN 978-953-307-532-7

Hard cover, 808 pages

Publisher InTech

Published online 21, January, 2011

Published in print edition January, 2011

This book provides an overview on a large variety of pesticide-related topics, organized in three sections. The first part is dedicated to the "safer" pesticides derived from natural materials, the design and the optimization of pesticides formulations, and the techniques for pesticides application. The second part is intended to demonstrate the agricultural products, environmental and biota pesticides contamination and the impacts of the pesticides presence on the ecosystems. The third part presents current investigations of the naturally occurring pesticides degradation phenomena, the environmental effects of the break down products, and different approaches to pesticides residues treatment. Written by leading experts in their respective areas, the book is highly recommended to the professionals, interested in pesticides issues.

\title{
How to reference
}

In order to correctly reference this scholarly work, feel free to copy and paste the following:

Brigita Tepuš, Irena Petrinić and Marjana Simonič (2011). Micropollutant Degradation Mechanism, Pesticides Formulations, Effects, Fate, Prof. Margarita Stoytcheva (Ed.), ISBN: 978-953-307-532-7, InTech, Available from: http://www.intechopen.com/books/pesticides-formulations-effects-fate/micropollutant-degradationmechanism

\section{INTECH}

open science | open minds

\section{InTech Europe}

University Campus STeP Ri

Slavka Krautzeka 83/A

51000 Rijeka, Croatia

Phone: +385 (51) 770447

Fax: +385 (51) 686166

www.intechopen.com

\section{InTech China}

Unit 405, Office Block, Hotel Equatorial Shanghai

No.65, Yan An Road (West), Shanghai, 200040, China

中国上海市延安西路65号上海国际贵都大饭店办公楼 405 单元

Phone: +86-21-62489820

Fax: +86-21-62489821 
(C) 2011 The Author(s). Licensee IntechOpen. This chapter is distributed under the terms of the Creative Commons Attribution-NonCommercialShareAlike-3.0 License, which permits use, distribution and reproduction for non-commercial purposes, provided the original is properly cited and derivative works building on this content are distributed under the same license. 